\title{
Performing Embodiment in Samuel Beckett's Drama
}




\section{Routledge Advances in Theatre and Performance Studies}

1. Theatre and Postcolonial Desires Awam Amkpa

2. Brecht and Critical Theory Dialectics and Contemporary Aesthetics Sean Carney

3. Science and the Stanislavsky Tradition of Acting Jonathan Pitches

\section{Performance and Cognition} Theatre Studies after the Cognitive Turn Edited by Bruce McConachie and

F. Elizabeth Hart

5. Theatre and Performance in Digital Culture

From Simulation to Embeddedness

Matthew Causey

6. The Politics of New Media Theatre Life ${ }^{\mathrm{T} M}$

Gabriella Giannachi

7. Ritual and Event

Interdisciplinary Perspectives

Edited by Mark Franko

8. Memory, Allegory, and Testimony in South American Theater

Upstaging Dictatorship

Ana Elena Puga

9. Crossing Cultural Borders Through the Actor's Work

Foreign Bodies of Knowledge

Cláudia Tatinge Nascimento
10. Movement Training for the Modern Actor

Mark Evans

11. The Politics of American Actor Training

Edited by Ellen Margolis and Lissa

Tyler Renaud

12. Performing Embodiment in Samuel Beckett's Drama

Anna McMullan 


\title{
Performing Embodiment in Samuel Beckett's Drama
}

\author{
Anna McMullan
}


First published 2010

by Routledge

270 Madison Avenue, New York, NY 10016

Simultaneously published in the UK

by Routledge

2 Park Square, Milton Park, Abingdon, Oxon OX14 4RN

Routledge is an imprint of the Taylor \& Francis Group, an informa business

\section{(C) 2010 Anna McMullan}

Typeset in Sabon by IBT Global.

Printed and bound in the United States of America on acid-free paper by IBT Global.

All rights reserved. No part of this book may be reprinted or reproduced or utilised in any form or by any electronic, mechanical, or other means, now known or hereafter invented, including photocopying and recording, or in any information storage or retrieval system, without permission in writing from the publishers.

Trademark Notice: Product or corporate names may be trademarks or registered trademarks, and are used only for identification and explanation without intent to infringe.

\section{Library of Congress Cataloging-in-Publication Data}

McMullan, Anna, 1957-

Performing embodiment in Samuel Beckett's drama / Anna McMullan.

p. cm. - (Routledge advances in theatre and performance studies ; 12)

Includes bibliographical references and index.

1. Beckett, Samuel, 1906-1989-Dramatic works. 2. Human body in literature.

I. Title.

PR6003.E282Z7767 2010

$842^{\prime} .914-\mathrm{dc} 22$

2009033521

ISBN10: 0-415-38598-9 (hbk)

ISBN13: 978-0-415-38598-5 (hbk) 
For Everett 


\section{$\Longrightarrow$ Taylor \& Francis Taylor \& Francis Group \\ http://taylorandfrancis.com}




\section{Contents}

Acknowledgments ix

1 Introduction 1

2 Dehiscent Bodies: From 'Le Kid' to Eleutheria 15

3 Intercorporeal Performances and the Hauntings of History in Waiting for Godot and Endgame

4 'This visible flesh': Krapp’s Last Tape and Happy Days 45

5 Mimes and Fragments: Corporeal Laboratories 57

6 Radiophonic Embodiments $\quad 67$

7 The Flesh of the Screen and the 'eye of prey': Beckett's Film 81

8 Unhomely Semblances and the Televisual Matrix 88

9 The Late Theatre: Performing Traces of Embodiment 105

10 Mutated Bodies: Stage Performances of Beckett's Late Prose Texts

11 Conclusion: Re-embodying Beckett's Drama in the Twenty-first Century

Notes

Bibliography

Index 


\section{$\Longrightarrow$ Taylor \& Francis Taylor \& Francis Group \\ http://taylorandfrancis.com}




\section{Acknowledgments}

This book was several years in the making, and I am grateful for the patience of my editor, colleagues at Trinity College Dublin and Queen's University Belfast, friends and family. The research for Chapter 10 was completed during my Fulbright Fellowship to New York University in 2004, and I thank the Fulbright Program; the Mabou Mines, especially Sharon Fogarty; Eileen Reilly and all at Glucksman Ireland House, New York University, which was a home from home; and the School of Drama at Trinity College Dublin who granted me a year's sabbatical. I thank the School of Languages, Literatures and Performing Arts at Queen's who granted me research leave to complete the book.

I have benefited enormously from the help and expertise of archivists at Trinity College Dublin, the Fales Library, New York University (especially the Senior Archivist, Ann Butler), the Harry Ransom Centre for the Humanities at the University of Texas, Austin, and the Beckett International Foundation, University of Reading (special thanks to Julian Garforth and to Mike Bott: although both have now left the University of Reading, they made a trip to the Beckett Collection a personal as well as professional joy; and to Mark Nixon of the Department of English and American Literature, University of Reading, for his generous assistance and advice).

Extracts from Samuel Beckett's letters to Barbara Bray, Ruby Cohn, Pamela Mitchell and unpublished manuscripts 'Coups de Gong / Espace souterrain' and 'Petit Odéon Fragments' are reproduced by kind permission of the Estate of Samuel Beckett c/o Rosica Colin Limited, London, the Board of Trinity College Dublin, and the Beckett International Foundation, University of Reading. I am particularly grateful to Edward Beckett for his assistance.

Material from the Mabou Mines Archive is reproduced by kind permission of the Mabou Mines and the Fales Library, New York University.

Some material has been published in earlier versions, and I am grateful to the following publishers for permission to reprint this material. 
'Embodying Alterity: Samuel Beckett's Theatre', in Beckett at 100: Revolving It All, eds. Linda Ben-Zvi and Angela Moorjani (New York: Oxford University Press, 2008), 166-176, reproduced by permission of Oxford University Press, Inc.

'From Matron to Matrix: Gender, Authority and (Dis)embodiment in Beckett's Theatre', in Women in Irish Drama: A Century of Authorship and Representation, ed. Melissa Sihra (Basingstoke: Palgrave Macmillan, 2007), 97-108, reproduced by permission of Palgrave Macmillan.

'Mutated Bodies: Stage Performances of Beckett's Late Prose Texts', Performance Research 12:1 (2007), 57-65, Taylor \& Francis Ltd, http://www.informaworld.com, reprinted by permission of the publisher.

'Samuel Beckett's "J.M. Mime": Generic Mutations of a Dramatic Fragment; Samuel Beckett Today/Samuel Beckett aujourd'hui 16 (2006): 333-345, reprinted by permission of Rodopi Press.

The subchapter on Krapp's Last Tape was presented to the Beckett Working Group at the Annual Conference of the International Federation for Theatre Research / La fédération internationale pour la recherche théâtrale at the University of Maryland, U.S., 26 June-1 July 2005, and I am grateful to the convenor, Linda Ben-Zvi, and participants for their responses.

Much of this material was discussed with advanced undergraduate and postgraduate students-a particular thanks to Jackie Blackman and Trish McTighe for insightful discussions and new directions in Beckett Studies. Thanks also to Louise Coats who always makes me see differently and goes straight to the soul of Beckett's work, and to Sarah Jane Scaife, for the uncompromizing spirit she brings to her extraordinary productions of Beckett's theatre. My greatest debt of thanks is to my husband and fellow Becketteer, Everett Frost. 


\section{Introduction}

Beckett's distorted and dismembered bodies have become part of the global cultural imaginary of the twenty-first century. Waiting for Godot has been canonized, and Beckett's iconic face has been appropriated in the marketing of his work and indeed in a number of advertising campaigns. ${ }^{1}$ Stan Gontarski comments on 'the growing number of allusions to [Beckett] and his work in popular culture' which is 'a measure of his cultural impact, part of his legacy as he is absorbed into and celebrated if not revered by a twentyfirst century global economy, and so a commodity in the culture industry' (2007: 1). In an era in which commodified and technologized visual culture disseminates phantasmatic corporealities (in commercial video games, for example), Beckett's disembodied heads or mouths may no longer seem as strange or disturbing as they once were. Yet I believe that it is precisely in its presentation of derogated, vulnerable bodies that struggle to appear and to speak that Beckett's drama continues to pose a challenge to contemporary culture and performance.

The performing body is both the medium and the recurrent subject of Beckett's theatre. The plays are extraordinarily reliant on the actor: in the later work there is frequently nothing but a body on stage, sometimes only part of one, like the isolated head of That Time. Such an intense visual focus on the fragmented body makes particular demands on performers, technicians and audiences. I propose to analyze in detail Beckett's presentation of the body in those media which depend on the corporeal interpretation of actors, the mediation of a creative and technical team, and a sensory mode of perception on the part of the listener/viewer that is materially different from the act of reading: in other words, theatre, film, television and radio.

My first encounter with Beckett's work was in the theatre, while I was a student at St Andrews University in Scotland in the late 1970s. To celebrate the launch of the Crawford Arts Centre ${ }^{2}$ in St Andrews, a festival of Beckett plays was presented, during which, in quick succession, I saw Waiting for Godot, ${ }^{3}$ Krapp's Last Tape, Not I and Footfalls. It was total immersion, a multi-sensory experience that I have never quite recovered from. I remember being mesmerized by images: from the domineering Pozzo in Godot, played as a skinhead, at once menacing and blustering with macho bravado, 


\section{Performing Embodiment in Samuel Beckett's Drama}

to the spotlit mouth and silent Auditor of Not I; and intrigued by sounds: the clatter when Lucky collapses off stage with all his paraphernalia of bag, stool and basket, the cork popping in Krapp's Last Tape as the constipated writer, Krapp, retreats to his den for his nightly tipple, and the reverberating chime and echoing steps of Footfalls. I recall a series of extreme corporeal states: the abject, slavering figure of Lucky with a rope around his neck in Godot, the babbling mouth in Not I, and the ghostly May in Footfalls, who, as Beckett famously commented to Billie Whitelaw, is 'not quite there' (Kalb 1989: 235). I am convinced that my investigation into Beckett's drama and into theatre itself over the last thirty years was shaped by this introduction to Beckett, not through reading, but through the complexly embodied medium of the stage and its simultaneously sensory and intellectual impact. Though I had no idea what it all 'meant', I knew that I had just experienced theatre as I had never known it, and that it left me not at all depressed or despondent, but reeling with discovery and urgency: who is this playwright Beckett? What is he doing with theatre? Why has it had such a profound, visceral impact on me? That sense of a radically interrogatory and innovative theatre whose creativity works on and through the body has stayed with me and was the impetus for this book.

My memory of particular productions is inevitably mediated by my textual readings, production research, and decades of teaching and discussing Beckett's drama with colleagues, friends and students, and vice versa. My focus on Beckett's dramatic practice as writer and director does not aim to prescribe an 'authentic' approach to performing or interpreting his texts, but rather to maintain what W. B. Worthen describes as 'the friction between writing and enactment that defines modern drama' (2005: 3). There have been many studies of Beckett's theatrical aesthetic and his approach to directing his own plays, and I am much indebted to them (for example, Linda Ben-Zvi, Ruby Cohn, Herbert Blau, Enoch Brater, Stanton Garner, Stan Gontarski, Jonathan Kalb and James Knowlson): what I hope this study will add is a focus on embodiment and a detailed examination of the wide range of dramatic media in which Beckett worked. ${ }^{4}$ I hope to explore both the challenge that Beckett's drama poses to the materials and conventions of particular media, and the ways in which it provokes modes of perceiving, conceiving and experiencing embodiment that address wider preoccupations with corporeality, technology and systems of power.

At the beginning of the twenty-first century, the body has become central to numerous artistic, critical, ethical, scientific and medical discourses and practices. Although I refer to some of the interdisciplinary studies on embodiment ranging across philosophy, gender studies and sociology (such as the work of Judith Butler, Thomas Csordas, Rosalind Diprose, Elizabeth Grosz), this book has drawn mainly on performance studies, understood in this context as a set of discourses specific to live and mediated performance (Philip Auslander, Herbert Blau, Peggy Phelan, Patrice Pavis, for example), ${ }^{5}$ phenomenology and psychoanalysis. These approaches resist any stable 
identification of the self with the visual image of the body and present embodiment as a complex negotiation of the boundaries between self and other, past and present, the lived body and the body image. This introduction presents the main conceptual frameworks that have informed my analyses of Beckett's dramatic works. However, because I frequently refer to the contexts in which the works were produced, which reference not just the text, but also Beckett's directorial contribution to the realization of the works on stage and in the aural and visual media, I would like to begin with some thoughts on the historical author, Samuel Beckett (1906-1989).

\section{SAMUEL BECKETT: THE EMBODIED AUTHOR}

\section{Which body? We have several. (Barthes 1977: 60)}

I believe that the historical contexts of Beckett's embodied life profoundly affected his work. Beckett's biography, letters, unpublished manuscripts and notes on staging offer important clues to his dramatic practice, and I frequently draw upon them in that spirit. But I am wary of anchoring meaning in 'Samuel Beckett' as any kind of stable signifier, coherent identity or origin. Beckett's work constantly resists such a notion, presenting identity as fractured in time ${ }^{6}$ and constructed through processes of representation, perception and identification. As several critics have noted, Beckett used his own experience as raw 'material' for his processes of composition (see especially Knowlson 2007). Indeed this process of 'making oneself up', in the words of one of the voices in That Time, is the central activity of most of Beckett's characters, so that their visible body or body part on stage is shadowed by remembered or imagined incarnations: May in Footfalls tells of her fictional alter ego Amy, a mirror image of herself, also dressed in tatters and pacing to and fro, so that, in the third section of that play, the audience seems to be watching a composite figure of May/Amy. Embodiment in Beckett's dramaturgy is no naïve return to the 'authentic' or 'natural' body, but, as the preceding Roland Barthes quotation suggests, complex and multiple. Beckett's work insists on the specifics of a particular historical, embodied existence, while refusing the conventions of narrative or corporeal coherence that usually define the representation of an individual life and body.

As I have argued elsewhere, the biographical, political and cultural contexts of post-independence Ireland, World War II and post-war Europe undoubtedly shaped Beckett's resistance to unitary or hegemonic definitions of proper and improper identities and bodies (McMullan 2004). Beckett vehemently refused the parameters of Irish cultural nationalism as he encountered it in the first decades of the Irish Free State. Although his writing draws on Irish or Anglo-Irish cultural references (such as Yeats, Synge or Berkeley) and on memories and landscapes from his childhood or early 


\section{Performing Embodiment in Samuel Beckett's Drama}

adulthood in and around Dublin, the unstable and fragmented identities in his work challenge any monolithic concept of Irish identity or a national 'tradition' of Irish writing. In 1937 he moved to Paris, and by the time Beckett began to compose his first full-length drama (Eleutheria) during an intensely creative period following his return to Paris after the war, he had been profoundly affected by the Nazi persecution and mass extermination of the Jewish people (see Blackman 2007), his involvement in the French Resistance, the years of refuge in Roussillon in the south of France from 1942 to 1945, and his work at the Irish Red Cross Hospital at St Lô, Normandy in 1946 (Knowlson 1996: 297-351). However, rather than directly representing these events, Beckett's post-war work testifies to his experience of cultural, linguistic and geographical dislocation, including his switch to writing in French, and to the shattering effects of the personal and historical trauma of the war and the Holocaust.

Beckett's dramaturgy resists the presentation of a coherent mimetic world: rather he worked to create a non-specific, meta-theatrical environment on stage (or the equivalent in fiction, film, radio and television) in which fragments of a past-that of the fictional persona and that of the author and his multilingual cultural 'appurtenances' (Katz 1999: 47)— are articulated as memories, ghosts or echoes. These fragments and layers are not recuperated into the stable contours of a normative identity or even a body: ' $[\mathrm{M}]$ uttering all over the parish till the words dried up and the head dried up and the legs dried up whosoever they were or it gave up whoever it was' (That Time, Beckett 1986: 392).7 In Beckett's texts, the regulation of proper norms of identity and behaviour through linguistic, social, cultural or political authority is regularly parodied or exposed as coercive, like the judge in Mouth's monologue in Not I: '[T]hat time in court ... what had she to say for herself ... guilty or not guilty ... stand up woman ... speak up woman' (381). In fact the term 'body' seems inappropriate to describe the fractured subjects and body parts of the late drama. I therefore prefer the term 'embodiment', which can accommodate the unstable and uncanny incarnations in Beckett's work, such as a mouth, a voice or even just an intake and outtake of breath. This term also shifts our focus from the exterior perception of bodies to the subjective experience of being embodied and, at the same time, engages a history of the ways in which bodies have been represented, imagined, analyzed and regulated. Embodiment in Beckett's work is presented as facticity (the historical details of a life), as vulnerable flesh, subjected to the corporeal and symbolic codes of a particular culture ${ }^{8}$ as imagined or phantasmatic ${ }^{9}$ material (dislocated body parts), and as site of subjectivity and imagining. What relations of power and authority are engaged in these processes of regulation, categorization, perception and imagination? To what extent is the individual body subjected to authority, and to what extent does the subject assert agency through imaginative re-embodiments-the embodied subject imagining his or her embodiment? How does Beckett's drama 
explore these questions through medium specific modes of performance and transmission/perception?

In order to explore the concept of embodiment further, I briefly consider the legacy of Cartesianism and the critical frameworks of psychoanalysis and phenomenology. Some of these can be connected to the facts of Beckett's life: his reading in philosophy and psychoanalysis, and his sessions of psychotherapy in the 1930s. However, I am also concerned to lay the foundations for my own approach to analyzing embodiment in Beckett's drama. Maintaining a kind of double vision encompassing both historical and contemporary perspectives can, I hope, foreground the ways in which the body is a not a stable historical entity, but, rather, as Dalia Judovitch argues,

emerges as a function of specific conceptual and cultural frameworks. For it is within particular discursive frames and practices that bodies 'materialize,' attaining their specific embodiments, be they literary, philosophical, social, anatomical, or technological ... At issue is an understanding of the body as an always provisional construction, grounded in changing worldviews that entail different understandings of representation, subjectivity, and identity. (2001: 3)

\section{REASON, IMAGINATION AND THE BODY: THE CARTESIAN LEGACY}

The prominence of discourses on the body in twentieth-century philosophy and criticism can be connected to a progressive unravelling of the Cartesian association of self-hood with the rational mind and the relegation of the body to the status of inert matter. In spite of Descartes's insistence on God as the ultimate guarantor of all knowledge, his philosophy marked the emergence of a new order based, as Dalia Judovitch argues, 'on the mathematization of knowledge and the world' (2001:3), and on an absolute distinction between mind and the material body. Beckett undertook a self-directed course of study in the history of Western philosophy in the 1930s that impacted on his writing directly in the 1930s and more indirectly after World War II (Frost and Maxwell 2006). These notes do not include Descartes, but we know that Beckett compiled substantial notes on Descartes's life and work, which he drew upon in the writing of his first published poem 'Whoroscope' (Harvey 1970: xi; Morot-Sir 1976: 47).

René Descartes (1596-1650) aimed to create a new method in philosophy that was not based in the authority of the ancient texts as in Scholasticism, but on scientific principles whereby certainty could be produced through rigorous rational reflection on the part of the philosopher. This entailed a methodology of doubt, where all existing knowledge is put in 
question, in order to re-establish what can be known from first principles. Hence the famous cogito ergo sum, I think, therefore I am, because the existence of the thinking mind itself cannot be doubted. The central tenet of Descartes's system is the division of the universe into res extensa, material substance, including the body, that is extended in space and time and is divisible; and res cogitans, thinking substance, that is not extended and cannot be divided, in other words, the mind. The essence of the 'I' therefore 'consists solely in the fact that I am a thinking thing'. Although 'closely joined' to the body, 'it is certain that I am really distinct from my body and can exist without it' (Descartes 1996: 54). In the Second Meditation, certain knowledge is located exclusively in the intellectual activity of the mind, because the evidence of the senses and of the imagination (which works on material furnished by the senses) can be misleading: 'I now know that even bodies are not strictly perceived by the senses or the faculty of imagination but by the intellect alone, and that this perception derives not from their being touched or seen but from their being understood' (22). Daniel Garber argues, 'Common sense, sensation, imagination are not eliminated. They remain part of Cartesian epistemology, but under the watchful eye and domination of reason' (2000: 255).

The Cartesian distinction between the thinking mind and the material body is particularly evident in Beckett's early fictional work. ${ }^{10}$ The narrator in Murphy describes 'the feeling, growing stronger as Murphy grew older, that his mind was a closed system, subject to no principle of change but its own, self-sufficient and impermeable to the vicissitudes of the body' (Beckett 1963: 64). Indeed, several critics have pointed out that the disjuncture between mind and body that recurs in Beckett's writing can be traced to the influence of a Belgian Cartesian, the Occasionalist philosopher Arnold Geulincx (1624-1669), who held that only the intervention of God permits the body to enact the mind's instructions ${ }^{11}$ (Descartes believed that mind and body, although distinct, communicated through the pineal gland). However, neither rational authority nor divine facilitation can be relied upon by Beckett's characters. Henry, in the radio play Embers, orders his body to stop or to sit down, but its recalcitrance is conveyed sonically: 'Stop. [Boots on shingle. As he goes, louder.] Stop! [He halts. Sea a little louder.] Down. [Sea. Voice louder.] Down!' (1986: 253). Malone remarks in Malone Dies, 'If I had the use of my body I would throw it out of the window' (1979: 201). Yet Beckett's work also insists on an embodied perspective and on the corporeal cost of the Cartesian myth of the autonomous, rational subject.

On the one hand, Cartesian doubt is pervasive throughout Beckett's writing, but, on the other hand, rational enquiry or system is continually parodied, emerging sometimes in a fascination with mathematics, 'one of the few satisfactions in life' (1986: 190) according to Dan Rooney in All That Fall, and sometimes, as in Play or What Where, in an interrogation that tortures its subjects. The knowledge and certainty that Descartes sought to establish are absent from the Beckettian world; what remains is 
the violence of epistemological inquisition: 'Bite off my tongue and swallow it? Spit it out? Would that placate you? How the mind works still to be sure!' (Beckett 1996: 314). As Edouard Morot-Sir emphasizes, it is the complex experience of both consciousness and embodiment that is presented in Beckett's work: 'Cartesian intellectualism is converted into an "affectivism" ... a direct and emotional experience of the body ... [Beckett's characters] feel their bodies and describe them as they feel them' (1976: 74). Beckett's poem, 'Whoroscope', presents Descartes not as a rational philosopher but as an irascible dramatic character (Morot-Sir: 56) tormented by fleshly decay and the relentless passage of time. The final stanza of the poem interconnects the making of an omelette, which Descartes preferred made of 'eggs hatched from eight to ten days' according to Beckett's notes accompanying the poem (Beckett 1984: 5), the maturation of Descartes's life or life's work, and the composition of the poem itself through the visceral image of the 'double breasted turd' which is 'ripe at last' (4). ${ }^{12}$ Although the Cartesian dream of escaping the material body haunts Beckett's characters, his oeuvre is embedded in the body's rhythms and processes.

Beckett's later plays, such as A Piece of Monologue, describe the process of utterance as a physical labour of expulsion or parturition: 'Stands there staring beyond waiting for first word. It gathers in his mouth. Birth. Parts lips and thrusts tongue between them. Tip of tongue. Feel soft touch of tongue on lips. Of lips on tongue' (1986: 428). This reflexive production of the voice by the speaker, and the speaker by the voice, suggests that the body/mind opposition may be dismantled through the corporeal efforts of self-articulation. ${ }^{13}$ I argue that Beckett's work explores not so much a dualist conception of embodied existence, as a fractured, multilayered one, composed and recomposed of flesh and imagination.

The critique of the sovereignty of reason invokes two other frameworks that were both concerned with dismantling the Cartesian legacy: psychoanalysis and phenomenology. Beckett was well acquainted with psychoanalysis in the 1930s, and likewise with some of the philosophers of phenomenology (Husserl, Heidegger and Sartre). Both psychoanalysis and phenomenology (particularly in the work of Merleau-Ponty and after), reconceive the relationship of the subject to the body, refusing the detached disembodied subject of Cartesian consciousness.

\section{PSYCHOANALYSIS: STAGING THE QUEST FOR A BODY}

Beckett underwent psychotherapy with Wilfred Bion at the Institute of Medical Psychology ${ }^{14}$ in London as a result of distressing somatic symptoms following the death of his father in 1933 (Knowlson 1996: 172-174)..$^{15}$ Around this time, Beckett also read a number of texts on psychology and psychoanalysis, keeping notes: these refer mainly to works by Karen Stephens, Ernest Jones, Sigmund Freud (although these notes consist mainly 


\section{Performing Embodiment in Samuel Beckett's Drama}

of summaries by Jones), Alfred Adler and Otto Rank, as well as general texts such as Robert Woodworth's Contemporary Schools of Psychology (Frost and Maxwell 2006: 157-166; Feldman 2006: 78-115). ${ }^{16}$ Beckett's notes present an intense, fragmented experience of the body, rooted in infant pleasures, cravings and denials deriving from the functions of sometimes interchangeable bodily organs such mouth, anus, urethra, genitals, as well as the body of others (the breast of the mother in the Stephens notes). Indeed, psychoanalysis views the subject as constituted from a network of bodily and psychic needs and impulses, thereby dismantling the Cartesian identification of self with the rational mind. Beckett's experience of the symptoms which led him to undergo psychotherapy, and his familiarity with various texts of psychology and psychoanalysis, seem to have shaped a particular focus on psychic distress and an identification with subjects in crisis, whose anxiety and dislocation rupture normative modes of identity and self-representation. ${ }^{17}$ Indeed, psychoanalysis casts both subject and body as works in progress, unfinished, always to be constituted or reconstituted, 'dreadfully un-' in the words of May in Footfalls.

Beckett's experiences and reading in psychoanalysis informed the development of his aesthetics in the late 1930s, when he was writing mainly poetry, fiction and literary reviews. As John Pilling notes, the latter functioned as an articulation of Beckett's own approach to art as critic and writer, and an attempt to define what direction his future would take at a time of immense uncertainty (1997). In two essays written in 1938, one unpublished in French, entitled 'Les deux besoins', and the second a review of Denis Devlin's poetry collection, Intercessions, published in the journal transition in 1938, Beckett located the art he admired in a dynamic of need, or in French 'besoin', transposing the psychoanalytic concepts of drive and desire into ontological and aesthetic terms. In his essay on Devlin, Beckett contrasts 'the need that in its haste to be abolished cannot pause to be stated and the need that is the absolute predicament of particular human identity' (1983: 91). In 'Les deux besoins', the condition of need from which the work emerges is specifically posited against a shoring of certainty and knowledge, encapsulated by Beckett in the image of those who, serene and sane of mind, allow nothing to question the solidity of the floorboards: 'Les autres, les innombrables béats et sains d'esprit ... ne laissent rien monter chez eux qui puissant compromiser la solidité des planchers' (55). In his review of Devlin's Intercessions, Beckett proposes instead 'the art that condenses as inverted spiral of need' (91). Rather than seeking truth, certainty or conclusions, such an art constitutes or rather dissolves self and world in endless questioning: '[P]ure interrogation-rhetorical question less the rhetoric' (91).

This concept of the subject in perpetual de-/recomposition has profound implications for the self-other mode of relation, and the boundaries of the body. In the Intercessions review, Beckett quotes from Devlin's poem 'Est Prodest', focusing not on Devlin's ultimate affirmation of human and divine 
love, but on his image of the self as splintered and refracted through the multiple mirrors of incarnate others. Beckett uses a psychoanalytic term 'cathexes' to describe Devlin's concept of identity as interconnected and reflexive: 'This is the type, the identity made up of cathexes not only multivalent but interchangeable, the "multiple netting / Of lives distinct and wrangling / Each knot all other's potential"' (1983: 92-93). Beckett's later work, especially the television work, will return to and materialize this sense of the subject's self-image as refracted through images of the other, drawing on a psychoanalytically informed understanding of the fluidity of the boundaries of self, body and other.

Jean Laplanche and Jean-Bertrand Pontalis argue that 'in psychoanalysis, the bounds of the body provide the model of all separations between an inside and an outside' (1973: 230). In particular, the relations between self and other are complicated by processes of projection and introjection. In projection, "qualities, feelings, wishes or even "objects" which the subject refuses to recognize are expelled from the self and located in another person or thing', whereas in introjection (a term that occurs in Beckett's notes from Karen Stephens ${ }^{18}$ ), 'the subject transposes objects and their inherent qualities from the "outside" to the "inside" of himself' (229). ${ }^{19}$ Both processes are modes of identification. Laplanche and Pontalis define identification as 'the psychical process whereby the subject assimilates an aspect, property or attribute of the other and is transformed, wholly or partially, after the model the other provides' (205). They emphasize that, in Freud's writings, identification is 'the operation itself whereby the human subject is constituted' (206). Judith Butler emphasizes the 'cross-corporeal' interconnections effected by these processes of identification:

Identifications belong to the imaginary; they are phantasmatic efforts of alignment, loyalty, ambiguous and cross-corporeal co-habitation; they unsettle the ' $I$ '; they are the sedimentation of the 'we' in the constitution of any 'I', the structuring presence of alterity in the very formation of the 'I'. (1993: 105)

Beckett's aesthetic of need acknowledges the culturally transgressive potential of such an unstable concept of identity. Kaja Silverman argues in Male Subjectivity at the Margins that forms of gendered identity and corporeality are shaped through identification with the dominant hegemonic codes of a particular regime: 'Hegemony hinges upon identification; it comes into play when all the members of a collectivity see themselves within the same reflecting surface' (1992: 24). Beckett's work shatters this hegemonic reflection, foregrounding the experience of subjects who fail or refuse to maintain the fiction of an autonomous, integral subject or body.

I argue that Beckett's drama produces new modes of intercorporeal embodiment out of the materials of subjection and vulnerability. In Precarious Life: The Powers of Mourning and Violence, Judith Butler refers to 'the 
problem of a primary vulnerability to others' (1994: xiv). She argues, 'We cannot, however, will away this vulnerability. We must attend to it, even abide by it, as we begin to think about what politics might be implied by staying with the thought of corporeal vulnerability itself' (29). Rather than indulgence in tragic despair, Beckett's theatre presents a radical transvaluation of vulnerability and otherness, using the public space of the stage to interrogate the laws and norms that judge and marginalize non-normative identities and bodies. I will argue that Beckett's drama foregrounds the limits of the material and mortal body, yet, especially in the later work, posits embodiment as both a given condition and a series of imagined incarnations to be witnessed by another. The mise en scène of the embodied subject articulating versions of embodiment before an assembly of witnesses is a major reference point of this study. It draws on a phenomenological understanding of both being and performance.

\section{EMBODIED ARTICULATION: MERLEAU-PONTY'S PHENOMENOLOGY}

As already cited, Morot-Sir has argued that Beckett's work focuses on the experience of embodiment: his characters 'feel their bodies and describe them as they feel them' (1976: 74). Several critics have drawn on phenomenology in an examination of the experiential quality of Beckett's writing. ${ }^{20}$ Although the phenomenological practice of bracketing existing knowledge recalls Descartes's methodology of doubt, phenomenology challenges the disembodied, abstract foundation of Cartesian knowledge by analyzing the subject's lived experience of both consciousness and phenomena. Edmund Husserl (1859-1938), generally recognized as the founder of phenomenology, a philosophical movement that includes Heidegger and Sartre, coined the term the 'lived body' (Leib) as opposed to the body-as-matter (Körper): '[N]aturalistically considered, all consciousness, and in general, all lived experience, is founded Bodily' (Husserl 1989: 193). However, the phenomenological philosopher who most radically theorized embodiment in the postWorld War II era, and who is consistently cited in contemporary writing about embodiment is Maurice Merleau-Ponty (1908-1961). Though there is no evidence that Merleau-Ponty directly influenced Beckett, Lois Oppenheim has demonstrated that they had historical, artistic and philosophical contexts in common (2000: 98-107): ${ }^{21}$ both attended the École Normale Supérieur at a similar time, both were profoundly affected by World War II and both were working through the legacies of dualist philosophies.

Merleau-Ponty's version of phenomenology insists on the subject's 'situated bodily perspective on the world' (Carman and Hansen 2005: 14). He therefore departs from the more transcendental phenomenology of Husserl, which argues that consciousness extracts an essential nucleus from its perceptions of the immediate phenomenal world. For Merleau-Ponty, 'the 
perceiving mind is an incarnated mind' (1964b: 3), and he refers to 'the incarnate subjectivity of the human body (1968: 167). This sounds rather far from Beckett's body-tormented personae. Yet, in Merleau-Ponty's writing, the incarnate subject is never coincident with the world or itself, ${ }^{22}$ because he (or she $)^{23}$ is both embodied and articulate: through the body, the subject is embedded in the world and, through speech or other creative acts (such as painting or philosophy), encounters and constructs the world anew. Phenomenology aims to reflect on and articulate this pre-reflective immersion in the world, asking 'what the world is before it is a thing one speaks of and which is taken for granted, before it has been reduced to a set of manageable, disposable significations' (1968: 102). By focusing on the experiential, the phenomenologist-artist makes 'our habitual evidences vibrate until they disjoin' (102), bringing about a 'dehiscence' (123) in the already constituted fabric of the perceptible world. Chapter 2 of this study investigates Beckett's version of such an aesthetics of dehiscence in his early writing and theatre. Although, as Ulrike Maude has argued (Maude 2002, 2009), there are many differences between Merleau-Ponty's agency-oriented philosophy and Beckett's depictions of the embodied condition, the lens that the former's philosophy offers can bring the latter's experiential dramaturgy into focus.

Merleau-Ponty argues that the embodied subject is both determined by the world and remakes the world. The world is constituted for the subject through perception and is already permeated by the inherited perceptions of others: 'Each landscape of my life ... a segment of the durable flesh of the world ... is qua visible, pregnant with many other visions besides my own . . . a visibility older than my operations on my acts' (1968: 123). Every gesture we make or word we speak engages us in the history of what has been done and spoken. The subject-artist such as Cézanne, however, 'takes up culture from its inception and founds it anew' (Johnson 1993: 69) by weaving the as yet unthought, unformed and invisible into its tangible fabric. Merleau-Ponty emphasizes the 'labour' of perception and articulation (129).

I will argue that Beckett's theatre, especially his late theatre, stages this process of the embodied subject attempting to articulate being through a corporeal effort of uttering and/or producing visible and audible traces (footfalls, for example), even though the personae ${ }^{24}$ of his drama are at times tenuously or partially embodied, and their efforts often produce only shadowy apparitions and echoes. Indeed, all of Beckett's works emphasize, however ironically or self-deprecatingly, the labour of making: in the extreme care with which they are crafted, and in the integration of that labour into the work itself, where Beckett's subjects struggle with the words available to tell their stories, or the fabric of aural or visual material through which to imagine a self (or an other). As Ruby Cohn argues in The Comic Gamut, 'No other modern writer-not Proust or Gide or Joyce or Mannhas integrated the act of creation so consistently and ironically into his own 


\section{2}

creation' (1962: 296). I am arguing that Beckett's artistic practice increasingly focuses on a phenomenological scrutiny of the embodied processes of articulation (a self, story or image) and the intercorporeal relations that this involves. Indeed, the work of both Beckett and Merleau-Ponty is characterized by an interrogatory disposition. Merleau-Ponty's The Visible and the Invisible posits 'interrogation as the ultimate relation to Being and as an ontological organ' (1968: 121), and he theorizes a non-violative, reflexive interchange between self and world, and past and present. ${ }^{25}$ Beckett's portrayal of intercorporeality and his interrogation of inherited structures of power and authority are darker, playing on the double meaning of interrogation as counter-questioning and as corporeal coercion.

Interrogation features in Beckett's first and last plays: in Eleutheria the Spectator, representative of normative theatre expectations, threatens to resort to the stereotypical figure of Chouchi, the Chinese torturer, in order to coerce Victor Krap into explaining his decision to leave the Krap family home and abandon all purposive activity; Beckett's last stage play, What Where, features cycles of torture in the attempt to elicit information. However, as in Merleau-Ponty's formulation, interrogation also signifies a radical questioning of the existing conceptions of how it is: in Eleutheria, Victor turns a counter-interrogatory gaze back on his fictional (and actual) spectators: 'It isn't me you should be interrogating. It's yourselves' (144). Beckett questions his own creative processes, as he often foregrounds the theatre itself (or the visual media) as a model of embodied relations of authority. As playwright and director, Beckett's dramatic authority is inscribed on the bodies of others, a material factor which recurs self-consciously in works such as Catastrophe, which places an actor's body on a plinth, while a Director and Assistant manipulate it as an object to be exhibited on stage.

\section{PERFORMING EMBODIMENT}

Throughout his oeuvre, Beckett's presentation of the body exploits the corporeal modes characteristic of the particular medium he was working in: from the narrative voice of the fiction producing a series of textually invoked bodies, to the materiality of sound and voice coming out of the dark in radio, the visually mediated bodies of television and film, or the live body in performance. It is hardly coincidental that many of the scholars who defined the field of theatre phenomenology have written on Beckett or include substantial chapters on Beckett (for example, Bert O. States, Bruce Wilshire, Stanton B. Garner and Alice Rayner). This study builds on work by Garner and others such as Herbert Blau, while drawing on analyses of the diverse dramatic media in which Beckett worked.

Drawing mainly on Husserl, Bert O. States discusses Beckett's plays in terms of theatre phenomenology in The Shape of Paradox: An Essay on Waiting for Godot (1978), and Great Reckonings in Little Rooms: On the 
Phenomenology of Theater (1985). States's concept of a 'bifocal' approach to performance analysis which negotiates between sensory, phenomenal experience, and semiotic interpretation is particularly relevant to a theatre which, as Beckett said of Not I, is geared more to the audience's nerves than to their intellect (Brater 1987: 23), yet has provoked pages of critical reflection. States describes his critical project as 'phenomenological in the sense that it focuses on the activity of theater making itself out of its essential materials: speech, sound, movement, scenery, text, etc' (1985: 1). Through a comparison of how the different theatrical genres of Shakespeare, realism and expressionism construct a world for the audience, States underlines the 'unique ontological confusion' (46) of the theatrical medium, which relies on a double vision of sensory perception and scenic and linguistic illusion. I suggest that this ontological doubleness was a major attraction of the theatrical medium for Beckett and one he self-consciously exploited. Later theatre phenomenologists such as Stanton B. Garner, Herbert Blau or Philip Auslander have acknowledged this complex ontology of theatre, with its layering of presence and illusion, the actual and the virtual.

Garner's Bodied Spaces: Phenomenology and Performance in Contemporary Drama includes an analysis of Beckett's theatre in relation to Merleau-Ponty's theories of embodiment, subjectivity and perception:

Beckett's drama is a theatre 'of the body,' both in a traditional sense that its characters are bodied forth by actors for spectatorial consumption and in a more deeply phenomenological sense in which Beckett foregrounds the corporeality of actor and character within his stage's exacting field. (1994: 28)

Garner foregrounds an important aspect of theatre phenomenology: it focuses on the perceptual and corporeal experience not only of the actors/ personae but also of the spectator. He argues,

The locus of Beckett's theater of the image remains the audience, that individual / collective 'third body' (along with character and actor) of the stage's intercorporeal field. For Beckett stages his spectator as deliberately as he does his characters, consciously manipulating the experiential orientations of audience to stage. (81)

The audience are not detached objective observers, but rather are positioned as an inherent part of the performance, though individual spectators may resist or redefine that role in particular performances/productions. I am looking at the ways in which Beckett's drama presents embodiment as site and condition of subjectivity, and as performative, ${ }^{26}$ constituted through an intercorporeal network of perception and interpretation, of interchanges between selves and others, including between the stage, screen or radio broadcast and the spectator/listener. 
This book follows a broadly chronological development of Beckett's dramatic work. However, in order to focus on Beckett's use of each medium, while acknowledging his intermedial experimentation, ${ }^{27}$ sections are devoted to each of the dramatic media, including theatre, mime, radio, film and television. Although this structure involves some repetition of key concepts and even quotes, they appear in a slightly different context in each chapter. Not all the work is discussed in detail: there are selections, which are partly pragmatic and partly chosen in relation to the core issues of performing embodiment. The chapter on Beckett's early work includes a selective discussion of some critical and fictional writing from the 1930s, introducing the motif of dehiscence as a way of approaching Beckett's first experiments with drama. Subsequent chapters explore concepts of intercorporeality and the undermining of vision as spectacle in the stage plays from Godot to Krapp's Last Tape. Because some sections overlap, the chronology is not strictly linear. Indeed, though one can trace an evolution towards increasing minimalism and the focus on a dislocated body and a disembodied voice in Beckett's drama, one can also witness strange loops, returns and metamorphoses between early and late work. For the most part, each chapter proceeds through close analyses of individual works, in order to give a sense of encountering them as pieces created for a particular medium, except for the chapter on the late theatre, which is organized around a number of recurrent motifs across these shorter plays and often picks up arguments that have been threaded throughout other chapters. I include a discussion of some of Beckett's early unperformed and in some cases unpublished drama and dramatic fragments, which I am approaching as laboratories for staging embodiment. The chapter on stage performances of Beckett's prose work analyzes the corporeal and technological vocabularies through which a selection of these productions transpose the fictional narrative/narrator to the embodied medium of theatre. Inevitably, the mutation from prose to stage creates a different entity, a cross-media translation which sustains a relationship with the prose text, but is clearly not identical to it. The adaptations I have chosen to investigate provide a forum for the analysis not only of the relationship between Beckett's creative practices in the different media of prose and theatre, but also of the material, perceptual and ontological conditions of theatre and the performing body. The conclusion reflects on the challenges of performing Beckett's bodies in the twenty-first century. 


\section{Notes}

\section{NOTES TO CHAPTER 1}

1. For example, Apple's appropriation of Beckett's image in their 'Think Different' advertising campaign.

2. Now Fife Contemporary Art and Craft.

3. In general I refer to play titles in English, unless, in the case of those works first composed in French, the French text, premiere or other French production is being referenced. Waiting for Godot will henceforth be cited as Godot.

4. Previous studies of the body in Beckett's theatre include Chabert (1982), Hubert (1987), Gontarski (2001) and Ben-Zvi (2009).

5. In its wider context, Performance Studies is a field of practice and research that is interdisciplinary and includes a broad range of approaches to cultural performances. Erin Striff notes, 'Performance is often perceived to be an activity that only takes place behind the proscenium arch or is contained within the box set. The discipline of performance studies has expanded upon this definition so that we can now see that performance is an inherent part of the customs, rituals and practices of cultures' (2003: 1). Nevertheless, she comments that 'in performance studies, we are never far from the theatre, whether or not we are considering traditional theatrical productions' (5). See also Schechner (2002) and Tracy C. Davis (2008).

6. In his essay on Proust, Beckett cites A la recherche du temp perdu: 'We imagine that the object of our desire is a being that can be laid down before us, enclosed in a body. Alas it is the extension to all the points in space and time that it has occupied and will occupy. If we do not possess contact with such a place and such an hour we do not possess that being. But we cannot touch all these points' (1965: 58).

7. Subsequent page references to The Complete Dramatic Works are given in brackets after the quotation.

8. See Michel Foucault (1977) on the production of 'disciplined bodies' through regulatory systems.

9. I will use the spelling 'phantasy' throughout to underline the psychoanalytic connotations of the term.

10. Critics have debated the influence of Descartes on Beckett's writing from Hugh Kenner's essay on 'The Cartesian Centaur' first published in the 1959 issue of Perspective (reprinted in Kenner 1968), Harvey (1970) and MorotSir (1976), to more recent studies such as Feldman (2006).

11. For example, Beckett directed Sighle Kennedy to the importance of Geulincx's dictum 'Ubi nibil vales, ibi nihil velis', usually rendered as 'there where you are worth nothing (or, alternatively can achieve nothing), there 
you should want (or not strive after) anything'. I am grateful to Everett Frost for discussion of the complexity of this phrase and Beckett's use of it (see Engelberts and Frost with Maxwell 2006: 141-155). Geulincx's Ethics has now been translated into English in an edition that includes Beckett's notes on Geulincx (Ruler and Uhlmann 2006).

12. This image also frequently appears in Beckett's correspondence of this period, as in a letter from Beckett to Thomas MacGreevy, 25 August 1930, referring to Beckett's own poems (Beckett 2009: 42-43).

13. Steven Connor vividly describes this process of 'giving voice' in Dumbstruck: A Cultural History of Ventriloquism (2000).

14. Feldman points out that the more familiar title of the Institute, the Tavistock Clinic, was demoted to a subtitle for several years following a move from Tavistock Square to Malet Street in 1930 (Feldman 2006: 161n23).

15. Knowlson indicates that Beckett's analysis lasted from December 1933 until December 1935.

16. These notes are held in Trinity College Dublin Library: MS 10971/7 and MS $10971 / 8$.

17. The many psychoanalytic readings of Beckett's work include Didier Anzieu (1992), Phil Baker (1997) and David Watson (1991).

18. TCD MS 10971/7, folios 3-4.

19. These processes are particularly acute in situations of loss or mourning, where the lost other may be incorporated into the self: '[T]he subject attempts somehow to preserve the object within the ego ... in a kind of hidden vault' (Hill 1992: 18). See also Kim (2005) and Tajiri (2007: 40-74).

20. Lois Oppenheim has published an authoritative study of Beckett and Merleau-Ponty's writings in The Painted Word: Samuel Beckett's Dialogue with Art (2000), and more recently, Merleau-Ponty features prominently in Ulrike Maude's Beckett Technology and the Body (2009), as well as in Beckett and Phenomenology (Maude and Feldman 2009).

21. Maurice Merleau-Ponty was co-founder with Jean-Paul Sartre and Simone de Beauvoir of Les Temps Modernes in 1945 and for several years its de facto political editor (Kruks 1981). A friend of Beckett's at the École Normale Supérieur, Jean Beaufret, became a prominent philosopher and Heidegger specialist, and defends Merleau-Ponty's arguments in the debate section of The Primacy of Perception (Merleau-Ponty 1964b: 41-42).

22. Stanton Garner tackles the critique of phenomenology in Thomas Trezise's Into the Breach: Samuel Beckett and the Ends of Literature (1990) which draws on Derrida's writings on Husserl (e.g., Derrida 1973). His argument that Derrida and Trezise attack phenomenology through its earliest manifestations in the work of Husserl, without taking into account Merleau-Ponty's significant revisions of Husserl's work, has been confirmed by more recent writing on Merleau-Ponty: 'Like Foucault and Lacan ... Derrida tends to view Merleau-Ponty entirely in the shadow of Husserl's essentializing transcendental project' (Carman and Hansen 2005: 22). Garner emphasizes Merleau-Ponty's acknowledgment that the embodied subject never coincides with itself: 'Since the body is both subject and object-as I can verify (to employ a Merleau-Pontean example) by touching one hand with the other-the subject's experience is caught up in ambiguity, in the impossibility of transcendental self-possession: the body I touch never coincides with the body that touches ... Beckett's drama explores the instability between a profound material inherence in the physical body and a corresponding alienation, and it dramatizes the subject's futile pursuit of any means for overcoming its own non-coincidence' (1993: 451).

23. Feminist critics have argued that Merleau-Ponty posits an undifferentiated body that is implicitly masculine and therefore neglects the negotiation of embodied 
difference (Irigaray 1993; Grosz 1994). However, several essays in Feminist Interpretations of Maurice Merleau-Ponty (Olkowski and Weiss 2006) offer alternative readings. For example, Judith Butler asks, 'To what extent does Merleau-Ponty's insistence on this prior world of flesh ... offer bodies a way to signify outside the binary trap of mothers and men' (2006: 121).

24. I find the term 'personae' or 'subject' more appropriate to refer to Beckett's creatures than the more conventional term 'character'.

25. However, Merleau-Ponty grappled with the violent repression of postrevolutionary Russia in Humanism and Terror: an Essay on the Communist Problem (1969) originally published in 1947.

26. Judith Butler's concept of performativity is inspired by J.L. Austin's concept of performative or 'illocutionary' speech acts, which do what they say, as in 'I sentence you to ten years' imprisonment', 'I bequeath my watch to you', or 'I pronounce you husband and wife'. However, for Butler, performativity, and, in particular, gender performativity, is not a singular "act", for it is always a reiteration of a norm or set of norms' (1993: 12) though this reiteration of convention is disguised as intentional action. Butler posits identity not as an essential core, but, rather, as constituted through the process of performing or failing to perform (abjection) regulatory norms which define 'a viable subject' (232).

27. Reworking a term from Theodor Adorno, Daniel Albright refers to this as Beckett's love of 'pseudomorphoses': '[A]ttempts by one medium to imitate the technical procedures of an alien medium' (2003: 7). See also Chapple and Kattenbelt (2006).

\section{NOTES TO CHAPTER 2}

1. Beckett regularly undertook paid translation work from 1930 through to the 1950s. These included translations into English from surrealists such as Andre Breton, René Crevel, Tristan Tzara, Jean Cocteau, French poets from Arthur Rimbaud ('The Drunken Boat') to Paul Éluard, Georges Duthuit's essays on painters, and translations from the Spanish for a UNESCO Anthology of Mexican Poetry (see Pilling 2006).

2. See Colin Duckworth's introduction to En attendant Godot (Beckett 1966: xlv).

3. By the time Beckett began to write Eleutheria, he had completed the novels Watt and Mercier et Camier, and the four Novellas 'The End', 'First Love', 'The Expelled' and 'The Calmative'. He began En attendant Godot after the novels Molloy and Malone meurt (Malone Dies), and before L'Innommable (The Unnamable).

4. 'The Possessed' is a highly stylized and overwrought dialogue or verbal 'contest' between two Professors who discuss 'Le Kid', originally published in TCD: A College Miscellany on 12 March 1931, reprinted and analyzed by McMillan and Fehsenfeld (1988: 21-22).

5. The irreverence of the piece also cocked a snook at the Modern Language Society itself, which had already been subjected to Beckett's taste for parody when he delivered a spoof lecture on 'Le Concentrisme' to the society the previous November, inventing a French poet, Jean du Chas (Knowlson 1996: 121-122).

6. This Festival of talks and productions of nineteen of Beckett's stage plays (excluding Eleutheria) was produced by the Gate Theatre Dublin in partnership with Radio Telefís Éireann and Trinity College Dublin.

7. Pelorson changed his name to Belmont after World War II, having been accused of collaborating with the Vichy régime. 
8. In Chapter 4 of Creative Evolution (published in English in 1911), Bergson emphasizes that we cannot approach duration intellectually, but rather intuitively.

9. A ghostly echo of Dr Levett's hiccup may perhaps be heard in that of M. in Play.

10. Beckett wrote a radio script entitled 'Capital of the Ruins' on the Irish Red Cross Hospital at St Lô for Radio Telefís Éireann, but it was never broadcast. The text is published in O'Brien (1986).

11. The Third Republic lasted from 1870 until the German invasion of France in 1940 and the establishment of the Vichy régime.

12. Ireland opted to remain officially neutral during World War II. See Clair Wills, That Neutral Island: A Cultural History of Ireland during the Second World War (2007).

13. Several critics have noted the autobiographical elements in the play: the son's rebellion against a bourgeois family, Victor's memories of diving with his father and the death of Victor's father (see Boxall 1998; Murray 2007); Knowlson cites both these and Beckett's dissatisfaction with the form of the play as reasons for its withdrawal from publication and performance (Knowlson 1996: 362-363). Beckett withdrew performing rights to the play after the success of En attendant Godot, and the play was not published until after his death. It has not yet had a professional production. Beckett's French text was published reluctantly by Les Éditions de Minuit in 1995, after an English translation by Michael Brodsky was published by Barney Rosset in New York. Beckett himself never translated the play into English. All references here are to the Barbara Wright translation (Beckett 1996).

14. David Bradby and Matthijs Engelberts demonstrate the play's similarities to Roger Vitrac's Victor ou les enfants au pouvoir, which premiered in 1928, but was republished and had an important Parisian revival in 1946, the year before Beckett wrote Eleutheria (Engelberts 2003: 5-6).

15. The Éditions de Minuit text has 'prenez un peu de contour, pour l'amour de Dieu' (Beckett 1995: 84).

16. For recent discussion of Beckett and testimony, see Jones (2008) and Katz (2009).

\section{NOTES TO CHAPTER 3}

1. A phrase used in Beckett's novel l'Innommable referring to the fictional characters of Mercier and Camier (1953: 16).

2. Roger Blin told Beckett that 'Eleutheria had too many characters for his very limited resources' (Knowlson 1996: 385). Eventually a grant of 500,000 old francs was obtained from the Ministry of Education for the production of En attendant Godot (as a first play) (386).

3. See McMillan and Fehsenfeld (1988: 68-80), Taylor-Batty and Taylor Batty (2008) and Bradby (2001) for an account of Blin's premiere production of En attendant Godot.

4. Taylor-Batty and Taylor Batty (2008) and Bradby (2001) give accounts of Beckett's 1975 Schiller-Theater production, and subsequent major productions of the play, including productions in Sarajevo (1993) and Haifa (1984).

5. See Connor (2009: 138): 'Beckett has a strong sense of what Heidegger might call "worlding”, the creation of worlds'. Connor cites Beckett's essay on Proust-'The creation of the world did not take place once and for all time, but takes place every day' (Beckett 1970: 19)—and relates Beckett's work to the concept of 'poverty in world' (137), as in Beckett's phrase in 
Three Dialogues with Georges Duthuit, about 'being short of world' (Beckett 1983: 143).

6. In his notebook in preparation for the Schiller-Theater production, Beckett also suggested two branches for the tree to create a 'third couple' (Knowlson 1994: 393).

7. This passage, spoken by Vladimir, is omitted in the English text: 'Ce soir on couchera peut-être chez lui, au chaud, au sec, le ventre plein, sur la paille' (Beckett 1952: 25).

8. Elin Diamond has analyzed the political implications of the relationships in Godot in terms of identificatory mechanisms: '[T]he misrecognition of the other and the concomitant enraged and irrational insistence that the other be me, be captured in my image, and if not, be cast from me, expelled, annihilated' (2001: 384).

9. In the 1975 Berlin production, Beckett emphasized that Pozzo subdues Lucky as much through a 'hypno' (hypnotic) look as through his whip (Knowlson 1994: 111). The tramps, on the other hand, exchange looks, observing each other.

10. Beckett did indicate a general conceptual structure for Lucky's 'Think' in his 1975 director's notebook: '5 sections: 1: Indifferent heaven, 2/3: Dwindling man, 4/5: Earth abode of stones \& cadenza' (Knowlson 1994: 57).

11. Knowlson comments that the actor Bud Thorpe's script from the 1984 San Quentin Drama Workshop production in which he played Vladimir 'contains the annotation "mental murder" by this line with arrows pointing to “corpses" and "skeletons" below' (1994: 151). The seeds of catastrophe seem to be latent in the structures of thinking itself.

12. Both Blackman (2007) and Katz (2009) suggest that Beckett was aware that by using the name Lévy, the character risked being perceived as a Jewish stereotype.

13. See Bradby (2001: 162-179). For a review (in Hungarian) of Godot-Ra Várva in Budapest 1994, directed by Darvas Iván, which interprets the production as articulating the Hungarians' disappointed waiting, first for socialism, and then for democracy, see http://www.criticailapok.hu/index. php?option=com_content\&view=article\&id=33823 (accessed 1 July 2009). Joseph Roach has discussed the incorporation of Waiting for Godot into The Oriki of a Grasshopper, written in the 1980s by Nigerian playwright Femi Osofisan. In Osofisan's play, the spaces of 'metaphysical' crisis in Waiting for Godot, which is being rehearsed in a university drama department, allow other layers of more local, immediate and socio-political crises to be substituted, from waiting for an actor to appear, with the knowledge that he may have been incarcerated, to waiting for social/political/economic revolution in Nigeria. See Roach (2001: 311). In The Haunted Stage (2001), Marvin Carlson has demonstrated the many ways in which specific productions, theatres and performer's bodies are layered by ghosts and histories.

14. Definition from the Concise Oxford English Edition (rev. 10th ed.).

15. 'The hammer and nails inevitably suggest the suffering of Christ, and in particular, the crucifixion. Throughout the play, then, all the banging, including Hamm's tapping on the wall, echoes this hammer-and-nail or crucifixion theme' (Gontarski 1992: 50).

16. Mother Pegg has also been associated with the parable of the wise and foolish virgins: 'Hamm was not about to share his oil with the foolish virgin and miss the opportunity for his own salvation' (Gontarski 1992: 67).

17. Whereas Godot is open to the surrounding space of the offstage, from which Pozzo and Lucky come and go, and which Estragon and Vladimir occasionally leave though they always return, no one comes and goes in Endgame, except Clov, and the audience only sees him go to and from his kitchen. Though there 
are references to his leaving the refuge in the text, Beckett cut these references when he directed the play-see Gontarski (1992: 312).

18. See Tajiri (2007) for a detailed exploration of prosthesis in Beckett's work.

19. See UoR MS 2926, one of the early drafts of Endgame with the characters referred to as A and B, and 'Avant Fin de Partie' UoR MS 1227/7/16/7.

20. In 'Avant Fin de partie', F's monologue locates their home or 'habitation' in Picardy, and notes that it has been progressively destroyed in the autumn 1914, spring of 1918 and the following autumn in mysterious circumstances! See Gontarski (1985: 33).

21. When Herbert Blau directed Endgame with The Actor's Workshop of San Francisco in 1959, the designer Robert LaVigne embedded a series of objects and fabrics in the walls, suggesting 'a sort of Western culture moving backward, inscribed on the gray walls' (2000: 53).

\section{NOTES TO CHAPTER 4}

1. In Techniques of the Observer: On Vision and Modernity in the Nineteenth Century, Jonathan Crary discusses the model of objective vision which became dominant in the seventeenth century, modeled on the apparatus of the camera obscura, and whose effect was to 'sunder the act of seeing from the physical body of the observer, to decorporealize vision' (1996: 39). The camera obscura presented 'an orderly projection of the world, and of extended substance ... made available for inspection by the mind' (46). Crary notes that, during the nineteenth century, this model began to be replaced by a more physiologically based concept of seeing, founded on the embodied, fallible eye, which therefore needed to be regulated and corrected through 'new technologies for imposing a normative vision on the observer' (16).

2. I have kept the presentational conventions of this revised text as published in Knowlson (1992: 3-10).

3. In the 1969 Schiller-Theater Werkstatt Production Notebook published in Knowlson (1992), Beckett refers to Krapp as a 'Träumgefressner Mensch' (239), eaten up by dreams.

4. As Knowslon and others have noted, this is a reference to the title of a poem by John Donne, in which the narrative persona resolves, 'And when I come where moving beauties be, / As men do when the summer's sun / Grows great, / Though I admire their greatness, shun their heat'. Norton Critical Editions: John Donne's Poetry, ed. A. L. Clements (New York: Norton \& Co, 1966), 43. Ironically, it is Krapp's own internal fire, rather than the heat from 'moving beauties', that consumes him.

5. For example: 'Beckett ... systematically interspersed the five Manichean "emblems" of light: zephyr, wind, light, quickening fire, clear water, with the emblems of dark: mist, heat, sirocco, darkness, vapour' (McMillan and Fehsenfeld 1988: 246).

6. See Knowlson (1992: xxiv-xxv): 'In a manuscript page owned by Jean Martin relating to the 1970 Récamier production, Beckett sets out precise, echoing actions for Krapp on every occasion when Bianca, the girl in the shabby green coat, the dark nurse and the girl in the punt are referred to. And in Beckett's Schiller and other later productions, Krapp always adopted the same look at these moments, raising his head from listening and going into the "dream" position'.

7. Knowlson (1992, 233-235): 'Third and longest look behind into shadows ... Magic eye built in recorder case faint [erasure] glow in dark till cut off by curtain'. 
8. See Elin Diamond's Unmaking Mimesis (1997) for a discussion of Butler's concept of 'performativity' in relation to theatre: 'Performance . . . is the site in which performativity materializes in concentrated form, where the "concealed or dissimulated conventions" of which acts are mere repetitions might be investigated and reimagined' (47). See also Jackson (2003).

9. Pierre Bourdieu defines the habitus as 'a subjective but not individual system of internalized structures, schemes of perception, conception, and action common to all members of the same group or class' (2008: 86).

10. In most of the productions I have seen which featured Irish actresses, including the 2007 National Theatre Production featuring Fiona Shaw, Winnie spoke with a middle-class Irish accent.

11. Happy Days, directed by Deborah Warner and designed by Tom Pye with Fiona Shaw as Winnie and Tim Potter as Willie, played at the Lyttleton Theatre, The National Theatre, London, from 18 January to 1 March 2007.

\section{NOTES TO CHAPTER 5}

1. Beckett's writing during this period included the series of fictional texts, Textes pour rien (Texts for Nothing), completed in 1951; the novel Comment C'est (How It Is), written between 1958 and 1960 (Pilling 2006: 143-149); and several shorter fictional texts such as the Fizzles, or 'From an Abandoned Work'. En attendant Godot premiered in 1953, Fin de partie (Endgame) was completed in 1956, Krapp's Last Tape in 1958 and Happy Days in 19601961. Beckett's first play for radio, All That Fall, was written in 1956, followed by Pochade and Esquisse radiophonique, Embers, Words and Music and Cascando, and a translation of Robert Pinget's play La Manivelle under the title The Old Tune, broadcast by the BBC Third Programme in 1960. Beckett wrote Film in 1963, and the television play Eh Joe in 1965.

2. Only Act Without Words I and II are published. 'J.M. Mime' is in Trinity College Dublin Archives and Manuscripts (TCD MS 4664), 'Mime du Rêveur A' is in the University of Reading Library Special Collections (UoR MS 1227/7/16/1) and 'Mongrel Mime' is held in the Harry Ransom Centre (University of Austin, Texas) Beckett Collection folder 17.7. 'Mime du rêveur A' and 'J.M. Mime' are published in facsimile as Appendices in Gontarski (1985).

3. See Mark Taylor-Batty, Roger Blin: Collaborations and Methodologies (2007). Barrault and his wife Madeleine Renault were already leading figures of French theatre in the 1950s, having set up the Compagnie RenaultBarrault in 1946. Madeleine Renaud played Winnie and Barrault Willie in the French premiere of Ob les beaux jours in 1963 at the Odéon Théâtre de France, Paris, directed by Roget Blin; Renaud played Mouth in Beckett's production of Pas moi at the Thêatre d'Orsay, Paris, in 1975; and Barrault the Protagonist in the premiere of Catastrophe at the Théatre du Rond-Point, Paris, 1983, directed by Michael Lonsdale. The Théâtre du Rond-Point was home of the Compagnie Renault-Barrault from 1981 to 1991.

4. See also Naito (2008).

5. Hans-Thies Lehmann identifies this primacy of the body as a characteristic of 'postdramatic' theatre: 'A shift in the understanding of sign production overall is at work when in postdramatic theatre an immediately imposing, often shocking physicality occurs. The body becomes the centre of attention, not as a carrier of meaning but in its physicality and gesticulation' (2006: 95).

6. In Beckett's mimes, the figure embodying the symbolic fable is often though not exclusively male. The script of Act Without Words I refers to 'the man'. However, Act Without Words II is a 'mime for two players'. Gender is not 
determined in Quad, and the 1982 Süddeutscher Rundfunk production had male and female performers.

7. The strategy of juxtaposing two states and two perspectives: one an exterior view of the embodied persona, and the second, an exteriorization of a dreamt, imagined or remembered self would be taken up in the later television play ... but the clouds ... and the televisual mime Nacht und Träume. Film took over the motif of the double using technology to embody a split between perceiving eye and perceived self. The play of gazes including a mirror was picked up in an abandoned draft for a television play in 1972, in which a figure scrutinizes her image in a videocassette, which appears to look back at her (UoR MS 2928).

8. Beckett's association with MacGowran dates from 1957, when Donald McWhinnie was producing All That Fall for the BBC Third Programme. Beckett heard a BBC radio broadcast of Michael Molloy's The Paddy Pedlar, in which MacGowran had a leading role, and he asked McWhinnie to cast him (Young 1987: 53). They met during the production of All That Fall, and a friendship developed that would last till MacGowran's death in 1973. In the early 1960s, Beckett was working with MacGowran on his one-man show 'End of Day', which later metamorphosed under Beckett's guidance into the highly successful show 'Beginning to End'. Indeed correspondence of the period suggests that Beckett wished to write something specifically for MacGowran to make up for his dropping End of Day (see letter to Barbara Bray of 10 December 1962, TCD 10948: 213). MacGowran's one-man show went through several mutations and incarnations, from a 'monstrous salad with good moments' (Knowlson 1996: 799, n117, citing Beckett), to 'the quintessence of Samuel Beckett' (Gussow 1970: 142).

'End of Day' was initiated in response to an invitation from the Dublin Theatre Festival in 1962. Beckett gave his approval, and MacGowran discussed the project with Beckett in Paris: 'Jack chose Act Without Words I, the author's elaborate "mime for one player," as a basic framework. He also selected a long, convoluted monologue from Waiting for Godot; a speech from Endgame; an except from the seminal novel, Molloy; a poetic passage from the radio play, All That Fall; an erotic reminiscence of a girl in a boat from Krapp's Last Tape; and the short prose piece, From an Abandoned Work, in its entirety' (Young 1987: 78). McWhinnie directed, Sean Kenny created a set that included a tree, and music from Miles Davis's 'Blue in Green' accompanied the show (78). The mime was the focus of the play, although MacGowran interspersed the mime sequences with spoken passages. Photographs of him show a mime artist's makeup (whitened face, heavily accentuated eyebrows) and costume (waistcoat with large incongruous button). This persona was self-consciously theatrical, with references to silent comedians such as Chaplin (the bowler hat) or Keaton. The show was well received at the Dublin Theatre Festival and transferred to the New Arts Theatre Club London. Beckett however, while very impressed with MacGowran's performance and delivery of the text, was unhappy with the thoroughly mixed format, indicating to MacGowran that '[a] mime is served best without words' (80). Around this time, Beckett began to write 'J.M. Mime' for MacGowran, which he subsequently abandoned, and he was Beckett's first choice for his not-quite-silent homage to silent film, Film, which features Buster Keaton. MacGowran featured in Beckett's first television play, Eh Joe, broadcast by the BBC in 1966.

In 1965, MacGowran returned to 'End of Day' but because Beckett was unhappy about its format and shape, during a visit by the actor to Paris, Beckett 'set about reconstructing an entirely different one' (Patrick Garland, quoted in Young 1987: 104). Miles Davis was replaced by the much more familiarly 
Beckettian Schubert's 'Death and the Maiden', which Beckett had incorporated into All That Fall. The mime was entirely excised (104), and MacGowran and Beckett developed the figure of a tramp, more closely modelled on the vagabond characters of Godot and the prose. The texts were reassembled, so that the first half of the show included poems and passages from the prose, the second mainly excepts from the plays. In 1969, Beckett and MacGowran again revisited the one-man show, whose format still troubled Beckett, honing in on the actor's performance and vocalization of the texts: all musical accompaniment was discarded, as well as 'the accoutrements he had used in previous versions of the show, the bowler hat, knapsack and walking stick' (132). The new show began with the opening pages of Malone Dies and concluded with the final words of The Unnamable (a copy of the script is held in the Beckett Collection of the Harry Ransom Centre, University of Texas, Austin). The show opened in Paris in April 1970 at the Théâtre Edouard VII, and had a very successful run in New York later in the year. Critics and reviewers tended to see this figure as Beckett's writing personified: Mel Gussow commented, 'This is not just a reading, or an impersonation, but an incarnation of the work and of the man' (1970). Harold Clurman in The Nation declared, 'I shall never again be able to think of Samuel Beckett's writing without associating it with the face, the flesh, the voice, the posture of Jack MacGowran' (7 December 1970).

9. See McMullan (2006) for a detailed analysis of 'J.M. Mime'.

10. The quincunx was originally a coin derived from the standard copper Roman coin, the as, which weighed twelve ounces (before it was reduced). The quincunx was worth five twelfths of an as.

11. Bill Worthen's Print and the Poetics of Modern Drama (2005) provides a detailed discussion of Beckett's use of text/reading in his plays, especially Ohio Impromptu.

12. John Pilling dates the mime as 1983 with acknowledged uncertainty (2006: 220). The date on the manuscript is unclear, and seems to have been altered, but I make it out to be 1963 (as does Ruby Cohn 2001: 277)—a much more convincing date, which would place its composition around the time of 'J.M. Mime' and Film, both of which were originally intended for Jack MacGowran.

13. Beckett presents disability as bearer of symbolic meaning in his earlier drama, especially blindness (Godot, Endgame, All That Fall). However, his later work interrogates the classification of normative or non-normative bodies and the tendency to read the body as marker of an essentialized or naturalized identity, focusing instead on the experience of embodiment.

14. 'Coups de gong / Espace souterrain' is held in Reading University Library: UoR MS 2932 and MS 2931, respectively. See Bryden, Garforth, and Mills (1998: 25-26).

15. MS 2931 describes the space as increasingly deserted using the word 'dépeuplé'.

16. The word occurs in Rimbaud's poem 'Le Bateau Ivre', which Beckett translated in 1932.

\section{NOTES TO CHAPTER 6}

1. BBC Radio presented Waiting for Godot on the Third on 27 April 1960, produced by Donald McWhinnie (Zillliacus 1976: 150). See Zilliacus for a detailed history of BBC Sound Drama in the era in which Beckett was writing for radio.

2. He submitted the script of All That Fall to the BBC at the end of September (Pilling 2006: 132). 
3. During this period of the late 1950s and early 1960s Beckett encountered a particularly sympathetic team of producers at the BBC Third programme, including Donald McWhinnie and Barbara Bray (Bignell 2009: 62-63).

4. McWhinnie became a close friend of Beckett and one of his preferred stage directors.

5. Pour en finir avec le jugement de dieu was recorded in November 1947 for Radio Diffusion Française, but was pulled the day before it was scheduled for broadcast in February 1948 (Barber 1993: 157).

6. See Morfee (2003) for a detailed discussion of Artaud's concept of the body in his late writing, and its differences from Deleuze's concept of the corps sans organs (body without organs) adapted from Artaud. See also Evelyne Grossman on Artaud, Beckett and Michaux (2004).

7. The title cites Robert Browning's 1855 poem 'Childe Rowlande to the Dark Tower Came', which in turn cites Shakespeare's reference to the medieval fairy tale of Childe (Knight) Rowlande in King Lear.

8. Beckett had just returned to writing in English with From an Abandoned Work which was published in Trinity News in June 1956.

9. Both quotations are from Beckett's letter to Barney Rosset, 27 August 1957, cited as frontispiece to Zilliacus (1976).

10. A hinny is the offspring of a male horse and a female donkey. They are usually sterile.

11. The citation is from Psalm 145:14.

12. The genre of 'Big House' fiction, initiated by Maria Edgeworth's Castle Rackrent (1800), refers to the historic houses of the Anglo-Irish Ascendency that fell into decline from the nineteenth century onwards. See, for example, Aidan Higgins, Langrishe Go Down (1966).

13. Broadcast by the BBC on 24 June 1959.

14. Since 1950, Beckett had experienced the death of his mother (1950), his brother Frank (1954), his friend Jack B. Yeats (March 1957), and, in December 1957, shortly before he mentions working on what would become Embers (Pilling 2006: 137), he heard that Ethna McCarthy had terminal cancer. Although we should be wary of over determining the interpretation of the play by 'explaining' it through biographical context, the play, like Krapp's Last Tape, written in 1958, seems permeated by a sense of loss and memory, worked out in fictional and technological terms.

15. Zilliacus cites Beckett on the importance of this radiophonic ambiguity to Embers (1976: 83).

16. See the entry on 'synthaesthesia' in Ackerley and Gontarksi (2004).

17. Beckett initially considered the title 'Ebb'. In a letter to Barbara Bray on 17 February 1959 (TCD MS 10948/19), Beckett lists some alternative titles, including 'On the Strand'; and adding 'why not Baile's', evoking W. B. Yeats's play, On Baile's Strand, and the figure of Cuchulain who famously and vainly fought with the sea. In On Baile's Strand, Cuchulain loses a son, but here, Henry has lost a father.

18. I am grateful to Eileen Denn Jackson for introducing me to this concept (Ph.D. thesis on 'Sonic Bodies in the Theatre of Paula Meehan', Trinity College Dublin, 2008). See also Finter (2007).

19. When Beckett revisited these motifs for the stage in Catastrophe, he would avoid any visual spectacularization of torture. Rather, using the theatrical medium against itself, he turns the spotlight on the very processes of turning a derogated body into a commodified spectacle.

20. Other productions of Words and Music have commissioned music from Humphrey Searle (in 1973; see Worth 1998) and Morton Feldman (in 1989, as part of The Beckett Festival of Radio Plays co-produced by Voices International and Westdeutscher Rundfunk [WDR] Germany; see Frost 1998 and 
1991). Searle also composed music for a production of Cascando discussed by Worth.

21. I am indebted to Everett Frost's paper 'Out of that Deep Considering Mind: Word Man meets Note Man in Samuel Beckett and John Beckett's / Morton Feldman's Words and Music', paper given at the Annual Conference of the Irish Society for Theatre Research, Dublin, 4 April 2008. Katherine Worth points out that Yeats entitled a collection of his poems 'Words for Music Perhaps' (1998: 9).

22. W. B. Yeats's poem 'The Tower' implicitly refers to the aging body as 'a sort of battered kettle at the heel'. In his late poem 'The Circus Animals Desertion', inspiration derives from 'the foul rag and bone shop of the heart'.

23. See Engelberts 2005/2006 for a discussion of Beckett and Orphic motifs.

\section{NOTES TO CHAPTER 7}

1. Much film theory (especially of the 1980s, such as Christian Metz, Stephen Heath, Laura Mulvey, Jacqueline Rose and Kaja Silverman) draws on psychoanalyst Jacques Lacan's theory of the mirror stage, where the child perceives in the mirror a visually whole image of the I, which contrasts with its actual, experiential sense of its body as an incoherent nexus of drives, a body in bits and pieces (un corps morcélé). At the same time, Lacan insists that this image of wholeness and self-reflection is a 'fiction' that will continue to haunt the subject with its 'mirage' of a coherent identity (2001: 1-7). The cinematic screen has been interpreted as a phantasmatic projection of the subject's desire for visual compensation for its experience of lack of being (see Metz 1982). Lacan himself posited a psychoanalytic concept of the screen as an arena in which the subject negotiates its visual identifications, explored in Chapter 8 of this study (see Sobchack 1992 on this concept in relation to Merleau-Ponty's theories of embodied vision).

2. The phrase 'eye of prey' occurs in Imagination Dead Imagine, written in 1965 (Beckett 1984: 147). The desire to see, not as a rational quest, but as a voracious hunger (which seeks to be satiated once and for all) is a recurrent motif in the prose, as in Text for Nothing I-'Eye ravening patient in the haggard vulture face perhaps it's carrion time' (73) - or at the end of Ill Seen Ill Said-'Grant only enough remain to devour all. Moment after glutton moment. Sky, earth, the whole kit and boodle' (Beckett 1982: 59).

3. See Knowlson (1996: 505) and Feshbach (1999). Rosset approached Beckett in late February 1963. Rosset's initial project also included commissioned scripts from Eugene Ionesco and Harold Pinter, but Beckett's was the only one he produced. Beckett worked on the script during April-May 1963 and submitted it to Rosset in late May. He flew to New York in July of 1964 to participate in the shooting of the film, with Alan Schneider as director and Boris Kaufman as cinematographer.

4. Bignell (2009) includes a detailed discussion of Keaton's films and subsequent reception. See also Brater (1987: 80).

5. Close Up was published from Switzerland, printed in England and France, and distributed in Paris, Berlin, London, New York and Los Angeles.

6. See Beckett's letter to MacGreevy of 29 January 1935 (for 1936), which mentions 'Pudovkin, Arnheim and back numbers of Close Up with stuff by Eisenstein' (Beckett 2009: 305). In this letter he also mentions his desire to work with Eisenstein in Moscow for a year. Beckett did indeed write to Eisenstein to apply for entry to the Moscow State School of Cinematography, but Eisenstein was struggling against increasing criticism in 
the Soviet Union, and did not reply, indeed may not have received the letter. By January 1937, Beckett was no longer pursuing that path. In January 1937, during his German trip of 1936-1937, he mentioned in a letter to Mary Manning Howe that, through the influence of André Malraux's brother, a place had been prepared for him 'at the court of Eisenstein in Moscow', but that he 'did not answer. Moscow is another journey' (Beckett 2009: 423).

7. See Brater (1987). Brederoo (1991) discusses other instances of eye imagery in surrealist/Modernist films.

8. Enoch Brater notes that 'the chase and escape gags resemble a crisis mimed in [Keaton's] Sherlock Junior (1924) where the hero studies a book called How to Be a Detective' (1987: 80).

9. According to Jonathan Bignell, 'The 45 degree rule whereby Keaton can be safe from the camera's perception if the camera remains behind him at less than this angle ... appears to allude to the impossibility of seeing oneself in a mirror if positioned beyond 45 degrees to one side' (2009: 194).

10. Trish McTighe, 'The Hungry Eye', paper given at the Annual Conference of the International Association for the Study of Irish Literatures (IASIL), Galway, 19 July 2007. Rather than seeking to possess an object, O's vision picks up gaps and tears in the visual field: the window, tattered curtain, the eyes of the chair that are like round holes. James Lastra invokes Gilles Deleuze and Felix Guattari's concept of 'faciality' in relation to Beckett's television play, Eh Joe, arguing that the screen constitutes 'a holey surface of the face' (2009: 66). For Deleuze and Guattari, faciality is an ideological system that reads faces, investing or divesting them with humanity: 'The faciality machine is not an annex to the signifier and the subject; rather; it is subadjacent (connexe) to them and is their condition of possibility' (1987: 170). In Film, $\mathrm{O}$ hides his face from passers-by not wanting to be seen, but perhaps also afraid that they will not recognize his face as a human subject. The emphasis on textures in the film-the creased eyelid, the walls and curtain-could be seen as effecting a de-facialization, where the face is replaced by the entire, disintegrating fabric/screen of the visible, on the one hand, and, as McTighe has argued, the haptic evocation of flesh, on the other: both are evoked in the open mouth of $\mathrm{O}$ at the end of the film.

11. The opening of Film in the script, which had to be abandoned because of shooting errors, emphasizes O's isolation and alienation from others. It establishes a populated public scene of a 'small factory district. Moderate animation of workers going unhurriedly to work' (324). The script specifically contrasts the anxiety of perception embodied in the $\mathrm{O} / \mathrm{E}$ relation through contrast with a series of couples who are 'all contentedly in percipere and percipi' (324). $\mathrm{O}$ is differentiated from this by his initial appearance: solitary and 'hastening blindly along sidewalk' and 'in opposite direction to all the others' (324).

12. That this ability to suffer self-consciousness is a specifically human attribute is emphasized in the script by the woman's pet monkey, who meets the camera with 'indifference' (35), though it is not present in the realized film. In the 'Notes', Beckett adds, 'The purpose of the monkey, either unaware of E or indifferent to him, is to anticipate the behaviour of animals in part three, attentive to $\mathrm{O}$ exclusively' (330).

13. Film was shown at Venice in September 1965.

14. After languishing in the archives for several decades, Karmitz's film was shown at the Musée d'Art Moderne, Paris, in June 2000, at the Anthony D'Offay Gallery in London in December 2000, and at the Venice Biennale in June 2001. The D'Offay gallery published a handsome bi-lingual French-English 
catalogue including an interview with Karmitz and other material (Karmitz and Beckett 2001).

15. See also Silverman's The Threshold of the Visible World (1995).

16. See Bersani and Dutoit (1993).

\section{NOTES TO CHAPTER 8}

1. In January 1966 Beckett went to London for the filming of Eh Joe, and it was broadcast on BBC2 on 4 July at 10:20 pm. Beckett had been working with Jack MacGowran on his one man show, 'Beginning to End', and planned two mimes for him, 'JM Mime' and 'Mongrel Mime', both of which were abandoned. Eh Joe was written for MacGowran.

2. McMullan (1998) and Maude (2009) discuss this essay in relation to Beckett's work in more detail.

3. This contrast between the objective body and the phenomenal body is often cited in the contemporary interdisciplinary field of cognitive science, for example, in the contrast between the body image and the more interactive body schema (see, for example, O'Donovan-Anderson 1996 and Gallagher 2005). Some of this reading has informed my tracing of the tension in Beckett's later work between a specular paradigm, and a more dynamic, interactive, performative paradigm of embodied self-composition.

4. See also Rabaté (1996) on Beckett's television drama: 'These apparitions are thus as much intertextual and literary as visual or auditory hallucinations-they depend on a discourse that rehearses different modalites of apparition' (38).

5. In The Visible and the Invisible, Merleau-Ponty defines philosophy as an interrogation of the already known and said in order to allow the possible and the alternative to emerge. So the words 'most charged with philosophy' are those which 'make our habitual evidences vibrate until they disjoin' (1968: 102). He continues, 'It is the possible worlds and the possible beings that are variants and are like doubles of the actual world and the actual being' (112).

6. In her essay on 'Beckett and the Uncanny', Lois Oppenheim focuses on Freud's interpretation of E. T. A. Hoffman's tale of 'The Sandman' as an anxiety about eyes and seeing, linked to a fear of castration. Oppenheim develops this into a wide-ranging discussion of the 'the mastering of visual perception' (2005: 139) in Beckett's work.

7. See Rosemary Pountney (1994) for a reading of Film in relation to the motif of the doppelgänger.

8. See the sections on elegy in Herren (2007).

9. Borch-Jacobsen distinguishes idiopathic from heteropathic identifications. In the latter case, 'instead of identifying the other with oneself, one identifies with the other, who therefore, in spite of everything, remains an other, orputting it more simply-remains' (213).

10. Stan Gontarski notes that in an earlier version of Eh Joe, Voice tells her own story of the suicide. Beckett then introduced a further level of substitution when Voice, devised by Joe, devises the 'green one' (1985: 118).

11. Given at the International Association for the Study of Irish Literatures (IASIL), University College Dublin, 19 July 2007.

12. Michel Chion also analyzes the power of the unlocated voice or acousmêtre in cinema in The Voice in Cinema (1999).

13. Knowlson points out a further ghostly reference, because Beethoven was working on an opera of Shakespeare's Macbeth as he was composing Geistertrio (1996: 621). 
14. Also written in the mid-1970s, the stage play Footfalls places a ghost-like figure within a formal structure (four part rather than triadic, though in fact she only appears in three of the four sections). Like F, May exists at the threshold of the visible and the invisible, the audible and the inaudible.

15. See, for example, the issue of the journal Performance Research 21:1 (2007), 'On Beckett', edited by Catherine Laws.

16. Musical serialism is a "compositional technique in which the twelve notes of the chromatic scale are arranged in a fixed order, the "series", which can be used to generate melodies and harmonies, and which normally remains binding for a whole work': The New Oxford Companion to Music (Oxford: Oxford University Press, 1983), ii, 1668. See also Tonning (2007: 62-63).

17. 'Beckett dramatized the rhythm of looking, a rhythm with which many painters are intimate. It oscillates between seeing and blindness, between figuration and abstraction, between the void at the center of sight and the contour of the slender ridge that brooks it' (Phelan 2004: 1280).

18. There is ambiguity as to whether the music is or is not diegetic-we do not see the figure turning the machine on or off in the first two parts, and in part two it is the Voice which commands the music to '[s]top' (411).

19. See also Meier (2001) and (2002).

20. ... but the clouds ... was written for the BBC Lively Arts programme, Shades, which broadcast Ghost Trio, ... but the clouds ... and a televisual version of Not I in 1977.

21. Marek Kedzierski argues that in Beckett's later stage work, 'the stage could be compared to a womb where an image born of the matrix of the mind is made visible and audible' (1994: 151). He goes on to suggest that in Beckett's television work, 'the screen replaces the stage as the locus of the mind's projections. It cannot accommodate the living actor, but only his sound-visual image' (15).

22. See Brown (2009) on Yeats's spiritual mediums and Beckett's use of the medium of television.

\section{NOTES TO CHAPTER 9}

1. The first production to bear Samuel Beckett's name as director was a staging of Robert Pinget's L'Hypothèse in 1965, at the Musée d'Art Moderne in Paris. This was the only time Beckett directed a play he had not written, and he became director as a result of having been taken by Robert Pinget to an early stage of rehearsals with the actor Pierre Chabert. This production was then repeated the next year in a Beckett-Pinget-Ionesco programme, for which Beckett also directed Va et vient (Come and Go). However, Gontarski points out that Beckett had been heavily involved in productions of his work since the early 1960s, including Roger Blin's production of Oh les beaux jours in October 1963, a production of Endgame with Jack MacGowran and Patrick Magee directed by Michael Blake at the Studio Champs-Elysées, Paris, in February 1964, and Anthony Page's production of Waiting for Godot at the Royal Court Theatre in December 1994 (1999: xxiii). Gontarski makes the point that Beckett then began to revise his earlier texts when he approached them as a director in rehearsal.

2. See also Auslander (2008) and Fuchs (1996).

3. In an interview with Linda Ben-Zvi, Billie Whitelaw spoke about being directed by Beckett in Not I: "He would keep reminding me, "No colour" (Ben-Zvi 1990: 5). She also noted her annoyance that some actor friends thought her voice was recorded (9).

4. How It Is, with its purgatorial mud out of which images 'up there in the light' are produced as a result of the infliction of extreme corporeal pain, can be 
linked to the purgatorial space of Play with its inquisitorial Light which provokes the three heads in their separate urns to tell their interlinked stories.

5. See Mary Bryden's section on listening in Bryden (1998: 24-32) and also Beckerman (1986).

6. Beckett remarked to the actress Jessica Tandy that he wished Not I to 'work on the nerves of the audience, not its intellect' (Brater 1987: 23).

7. As mentioned in Chapter 8, 'eye of flesh' occurs in The Lost Ones (Beckett 1984: 167) and in Ill Seen Ill Said (Beckett 1982: 17, 30), and the Yeatsian phrase from At the Hawk's Well 'I call to the eye of the mind' recurs in Happy Days (Beckett 1986: 164).

8. Nelly Richards (1986, cited in Warr 2000: 244) uses this phrase in relation to the work of the Chilean artist, Carlos Leppe.

9. My earlier monograph, Theatre on Trial: Samuel Beckett's Later Drama, is organized around close readings of individual plays. I have therefore not reproduced those here, but rather cross-reference the plays in relation to recurrent motifs relating to the performance of embodiment. The individual contexts of production of each play are therefore not referenced in the text, but the dates of their premieres are given here: all of these plays were initially written in English except Catastrophe and Quoi Où (What Where): Play (1963, in German translation by Elmar and Erika Tophoven titled Spiel at the Ulmer Theater, Ulm-Donau directed by Derek Mendel, English-language premieres 4 January 1964 at the Cherry Lane Theater, New York, directed by Alan Schneider, and on 7 April 1964, at the Old Vic Theater, directed by George Devine); Come and Go (1966, in German translation by Elmar Tophoven titled Kommen und Gehen at the Schiller-Theater Werkstatt, Berlin, directed by Deryk Mendel, English-language premiere at the Peacock Theatre, Dublin, directed by Edward Golden), Breath (1969, written in response to Kenneth Tynan's request for a contribution to his review $\mathrm{Ob}$ Calcutta and first produced at the Eden Theater, New York); Not I (1972 at the Forum Theater of the Lincoln Centre, New York, directed by Alan Schneider); That Time (1976 at the Royal Court Theatre, London, directed by Donald McWhinnie); Footfalls (1976, on the same bill as That Time at the Royal Court Theatre, directed by Samuel Beckett); A Piece of Monologue (1980, Annex at La Mama, New York, performed by David Warrilow); Rockaby (1981 at the State University of New York at Buffalo, directed by Alan Schneider); Obio Impromptu (1981, Ohio State University directed by Alan Schneider); Catastrophe (1982 at the Avignon Festival, France); Quoi Où (1983, in German translation by Elmer Tophoven, titled Was Wo, at Theater im Malersaal, Graz, directed by Kurt Josef Schildknecht, English-language premiere in 1983 at the Harold Clurman Theatre, New York, directed by Alan Schneider). My thanks to Stan Gontarski for his assistance.

10. This sense of the vital creative potential of recomposing the body owes much to Paul Schilder's important and influential study, The Image and Appearance of the Human Body, first published in 1935. He emphasizes that the 'experience of our body-image and experience of the bodies of others are closely interwoven with each other', and argues that the 'postural model' of the body is in 'continual self-construction and self-destruction' (2000: 15-16).

11. The phrase is taken from Samuel Beckett's tribute to Avigdor Arikha: 'Siege laid again to the impregnable without. Eye and hand fevering after the unself. By the hand it unceasingly changes the eye unceasingly changed. Back and forth the gaze beating against unseeable and unmakeable. Truce for a space and the marks of what it is to be and be in face of. Those deep marks to show' (1983: 152).

12. Those otherworldly disembodied hands will recur in Nacht und Träume.

13. Version sent to Barbara Bray, 16.8.1962, TCD MS 10948/190. 
14. The play is dedicated to Vaclav Havel, who was incarcerated at the time.

15. As Luce Irigaray has noted, in patriarchal cultures, the daughter suffers from a lack of individuation, as the only culturally significant roles are those of wife and mother (1991).

16. See Peter Boxall's reading of Ohio Impromptu (2004).

17. Thomas Laqueur (1990) emphasizes that binary sexual classification is also a historical construct.

18. See Tajiri (2007) and Maude (2009).

19. This section is much indebted to Kalb (1989), Ben-Zvi (1990), Whitelaw (1996) and Zarilli (2009).

20. See, for example, McConachie (2007) and Foster (2008).

21. David Warrilow had a different but equally profound effect on me as I felt entirely engulfed in the musical yet visceral depths of his voice: he used his voice and his body like the instruments of a consummate player, yet he also conveyed a quality of corporeal vulnerability, especially in his last performances.

22. The title of Dr Ronan McDonald's lecture on Samuel Beckett at Trinity College Dublin on 2 April 2009.

\section{NOTES ON CHAPTER 10}

1. See entry under 'adaptations', Ackerley and Gontarski (2004: 5-6), and Cooke (1987). The adaptations in which Beckett actively intervened include the collation of dramatic, poetic and prose texts performed by the Irish actor Jack MacGowran as 'End of Day' in 1962, and subsequently revised as 'Beginning to End'; Shivaun O'Casey's adaptation of From An Abandoned Work which toured the United States in 1963; and Joseph Chaikin's stage version of Texts for Nothing, first staged in 1981 with Chaikin performing, and subsequently restaged, after Chaikin's stroke in 1984, with Bill Irwin directed by Chaikin. In interview with Mel Gussow in 1973, MacGowran refers to Beckett directing his anthology in Paris and being 'very concerned with movement, with the way a head should be turned (Gussow 1996: 23). Beckett also suggested staging concepts to O'Casey and Chaikin. In the case of From an Abandoned Work, Beckett suggested that the text should be found in an 'ashcan' by the performer on stage, read and then replacedthe text as entirely 'alien' to the reader, literalizing the abandonment of the title. In correspondence with Chaikin, Beckett developed a mise en scène which also dramatized the production of the text itself: 'Samuel Beckett's figure "A" has an unnamed collaborator, an external Other, as much audience to the emerging artwork as instigator, as he folds the voices of Others, origins unknown into his own' (Ackerley and Gontarski 2004: 5). In each of these cases, Beckett was resisting any attempt to dramatize the story, its events or characters, but rather the conditions of its production, provenance or utterance.

2. For example, Pierre Chabert's production of Mercier et Camier, Théâtre du Rond-Point, Paris, 1988.

3. The term is taken from a letter from Beckett to Alan Schneider in relation to the proposed filming of the 1975 Schiller-Theater production of Godot in Berlin: 'Berlin wasn't too bad in the end. We were nearly there. There will be a film of a performance, purely documentary, no adaphatroce' (Harmon 1998: 324).

4. See also Engelberts (2001) and Ouimet (1992). Albright uses the term 'pseudometamorphoses' (2003: 7). 
5. At time of writing, Breuer, Maleczech and Neumann are still active in the New York-based company. See the Mabou Mines Web site: http://www. maboumines.org.

6. The Mabou Mines Archive (hereafter cited as MMA) MSS 133, The Fales Library, New York University: Production Files Folder 7.

7. Video of The Lost Ones MMA, Production Files, Folder 7.

8. See Ulrike Maude's chapter 'Skin deep' for a detailed analysis of Beckett's prose text of The Lost Ones (2009: 70-82).

9. Independent arts funding agency of the U.S. federal government.

10. MMA, Production Files, Imagination Dead Imagine, Folder 24.

11. MMA, Production Files, Imagination Dead Imagine, Folder 24. As the project statement mentions, the projected hologram was at the cutting edge of experimentation with the artistic possibilities of holography. A great deal of research was carried out in relation to existing technological expertise and the main experts in holograph construction in the U.S. were consulted. The Holographic Film Foundation provided an artist's grant, which aimed specifically 'to contribute to the development of the artistic language of this new medium' (Folder 24).

12. This is a recurrent trope in Beckett, for example, his poetry collection 'Echo's Bones'.

\section{NOTES TO THE CONCLUSION}

1. There has been much debate over the ethics of Beckett's creative practice. Shane Weller has argued that Beckett discourages the adoption of any clear ethics of alterity, and he proposes the model of a Beckettian 'anethics'-'not of a new art or ethics, but rather of ways in which the experience of disintegration of both art and ethics might be rendered visible-or audible-on a page or a stage' (2006: 194). By all accounts, Beckett did not write with any aim of intervening in political or ethical debates: he continually insisted that he wrote out of need, or, as reported by Charles Juliet, 'in order to be able to breathe' (1995: 153). However, I would argue that the dismantling of the objective, rational position of knowledge, judgement or classificatory power that de-humanizes its objects, and the revelation of the fundamental vulnerability and instability of embodied life poses ethical and aesthetic challenges. See Smith (2009). 


\section{Bibliography}

\section{ABBREVIATIONS}

Journal of Beckett Studies: JOBS

Samuel Beckett Today / Samuel Beckett Aujourd'hui: SBTA

\section{PUBLISHED WORKS}

Abbott, H.P. (1996) Beckett Writing Beckett: The Author in the Autograph, Ithaca, NY \& London: Cornell University Press.

Ackerley, C.J. and Gontarski, S.E. (eds.) (2004) The Grove Companion to Samuel Beckett: A Reader's Guide to his Works, Life and Thought, New York: Grove Press.

Adorno, T. (1981) Prisms, trans. S. Weber Nicholsen and S. Weber, Cambridge, MA: MIT Press.

- (1982) 'Trying to Understand Endgame', trans. M. T. Jones, New German Critique (26) 119-150.

- (2003) Can One Live After Auschwitz? A Philosophical Reader, ed. R. Tiedemann, trans R. Livingstone et al., Stanford, CA: Stanford University Press.

Admussen, R. (1979) The Samuel Beckett Manuscripts, Boston: G.K. Hall \& Co.

Albright, D. (2003) Beckett and Aesthetics, Cambridge: Cambridge University Press.

Amossy, R. (1981) 'Toward a Rhetoric of the Stage: The Scenic Realization of Verbal Clichés', Poetics Today (2: 3) 49-63.

Antoine-Dunne, J.M.B. (2001) 'Beckett and Eisenstein on Light and Contrapuntal Montage', SBTA (11):315-323.

Armstrong, T. (1998) Modernism, Technology and the Body: A Cultural Study, Cambridge: Cambridge University Press.

Arnheim, R. (1936) Radio, trans. M. Ludwig and H. Read, London: Faber and Faber. - (1957) Film as Art, Berkeley: University of California Press.

Anzieu, D. (1992) Beckett et le psychoanalyste, Paris: L'Aire / Archimbaud.

Artaud, A. (2003) Pour en avoir finir avec le jugement de dieu, Paris: Gallimard.

Auslander, P. (2008) Liveness: Performance in a Mediatized Culture, London: Routledge.

Badmington, N. (ed.) (2000) Posthumanism, Basingstoke: Palgrave Macmillan.

Baker, P. (1997) Beckett and the Mythology of Psychoanalysis, London: Macmillan.

Barber, S. (1993) Antonin Artaud: Blows and Bombs, London \& Boston: Faber \& Faber.

Barthes, R. (1977) Roland Barthes by Roland Barthes, trans. R. Howard, Basingstoke: MacMillan. 


\section{Bibliography}

. (1982) Camera Lucida: Reflections on Photography, trans. R. Howard, New York: Hill and Wang.

Bazin, A. (1959) Qu'est-ce que le cinéma?, vol. 2, Paris: Cerf.

Beckerman, B. (1986) 'Beckett and the Act of Listening' in Beckett at 80 / Beckett in Context, ed. E. Brater, Oxford \& New York: Oxford University Press, 149-167.

Beckett, S. (1952) En attendant Godot, Paris: Éditions de Minuit.

. (1953) l'Innommable, Paris: Éditions de Minuit.

. (1963a) Murphy, London: John Calder.

- (1963b) Watt, London: John Calder.

- (1966) En attendant Godot, London: Harrap.

. (1970) Proust and Three Dialogues with Georges Duthuit, London: John Calder.

- (1979) The Beckett Trilogy: Molloy, Malone Dies, The Unnamable, London: Picador.

. (1982) Ill Seen Ill Said, London: John Calder.

. (1983a) Disjecta: Miscellaneous Writings and a Dramatic Fragment, ed.

R. Cohn, London: John Calder.

- (1983b) Worstward Ho, London: John Calder.

. (1984) Collected Shorter Prose, London: John Calder.

. (1986) The Complete Dramatic Works, London: Faber \& Faber.

(1993) Dream of Fair to Middling Women, London: John Calder.

(1995) Eleutheria, Paris: Minuit, 1995.

(1996) Eleutheria, trans. B. Wright, London: Faber \& Faber.

(2009) The Letters of Samuel Beckett, vol. 1, 1929-1940, ed. M.D.

Fehnsenfeld and L. Overbeck, with C. Craig and D. Gunn, Cambridge: Cambridge University Press.

Belmont, G. and Calder, J. (2002) 'Remembering Sam', in Beckett in Dublin, ed. S.

Wilmer, Dublin: Lilliput Press, 111-128.

Benjamin, W. (1968/1992) Illuminations, London: Fontana.

Benson, M. (1987) 'Blin on Beckett', in Beckett: Waiting for Godot, ed. R. Cohn, Casebook Series, Basingstoke: Macmillan, 26-28.

Benstock, S. (1990) 'The Transformational Grammar of Gender in Beckett's Drama', in Women in Beckett: Performance and Critical Perspectives, ed. L.

Ben-Zvi, Urbana and Chicago: University of Illinois Press, 172-186.

Ben-Zvi, L. (ed.) (1990) Women in Beckett: Performance and Critical Perspectives, Urbana and Chicago: University of Illinois Press.

- (ed.) (2003) 'Drawing on Beckett', special issue of Assaph (17-18).

. (2004) 'Biographical, Textual and Historical Origins', in Palgrave Advances in Samuel Beckett Studies, ed. L. Oppenheim, Basingstoke: Palgrave: 133-153.

- 'Beckett, McLuhan, and Television: The Medium, the Message, and the "Mess" in Beckett at 100: Revolving It All, eds. L. Ben-Zvi and A. Moorjani, 271-284.

- (2009) 'Beckett's Bodies, or Dr Johnson's "Anatomy Lesson"', in Reflections on Beckett: A Centenary Celebration, eds. A. McMullan and S. Wilmer, Ann Arbor: University of Michigan Press, 9-31.

and Moorjani, A. (eds.) (2008) Beckett at 100: Revolving It All, Oxford: Oxford University Press.

Bergson, H. (1911) Creative Evolution, trans. A. Mitchell, New York: Henry Holt \& Company.

. (1912) Matter and Memory, trans. N.M. Paul and W. Scott Palmer, London: George Allen \& Co. / New York: The Macmillan Co.

Bersani, L. and Dutoit, U. (1993) Arts of Impoverishment: Beckett, Rothko, Renais, Cambridge, MA: Harvard University Press.

Bignell, J. (2009) Beckett on Screen: The Television Plays. Manchester: Manchester University Press. 
Blackman, J. (2007) 'Beckett Judaizing Beckett: A “Jew from Greenland” in Paris', SBTA (18) 325-349.

- (2009) 'Post-war Beckett: Resistance, Commitment or Communist Krap?' in Beckett and Ethics, ed. R. Smith, London: Continuum, 68-85.

Blau, H. (1982) Take Up the Bodies: Theatre at the Vanishing Point, Urbana: University of Illinois Press.

- (2000) Sails of the Herring Fleet: Essays on Beckett, Ann Arbor: University of Michigan Press.

Bleeker, M. (2008) Visuality in the Theatre: The Locus of Looking, Basingstoke: Palgrave Macmillan.

Borch-Jacobsen, M. (1989) The Freudian Subject, trans. C. Porter, Basingstoke: Macmillan.

Bordo, S. (1987) Flight to Objectivity: Essays on Cartesianism and Culture, New York: State University of New York Press.

- (1993) Unbearable Weight: Feminism, Western Culture and the Body, Berkeley: University of California Press.

Bourdieu, P. (1977/2008) Outline of a Theory of Practice, trans. R. Nice, Cambridge: Cambridge University Press.

Boxall, P. (1998) 'Freedom and Cultural Location in Eleutheria', SBTA (7) 245-259.

- (2003) Waiting for Godot and Endgame: A Reader's Guide to Essential Criticism, Basingstoke: Palgrave.

- (2004) 'Beckett and Homoeroticism' in Palgrave Advances in Samuel Beckett Studies, ed. L. Oppenheim, Basingstoke: Palgrave Macmillan, 110-132.

Bradby, D. (2001) Waiting for Godot, Cambridge: Cambridge University Press.

Braidotti, R. (2006) 'Posthuman, All Too Human: Towards a New Process Ontology', Theory Culture Society (23:7-8) 197-208.

Brater, E. (1985) 'Toward a Poetics of Television Technology: Beckett's Nacht und Träume and Quad', Modern Drama (28:1) 48-54.

- (ed.) (1986) Beckett at 80 / Beckett in Context, Oxford \& New York: Oxford University Press.

- (1987) Beyond Minimalism: Beckett's Late Style in the Theater, Oxford \& New York: Oxford University Press.

- (1994) The Drama in the Text: Beckett's Late Fiction, New York: Oxford University Press.

Brederoo, N. (1991) 'Beckett's Film: An Essay', trans. O. Kosters, SBTA (1) 158-170.

Brown, R. (1970) 'Television and the Arts', in The Effects of Television, ed. J.D. Halloran, London: Panther, 105-137.

Brown, T. (2009) 'Yeats and Beckett: The Ghosts in the Machines', in Reflections on Beckett: A Centenary Celebration, ed. A. McMullan and S. Wilmer, Ann Arbor: University of Michigan Press, 40-52.

Bryant-Bertail, S. (1995) 'The True-Real Woman: Maddy Rooney as Picara in All That Fall', Assaph (11) 1-17.

Bryden, M. (1993) Women in Samuel Beckett's Prose and Drama: Her Own Other, Basingstoke \& London: Macmillan.

- (1994) 'Quad: Dancing Genders', SBTA (4) 109-122.

. (ed.) (1998a) Samuel Beckett and Music, Oxford: Clarendon Press.

- (1998b) Samuel Beckett and the Idea of God, Basingstoke: Macmillan.

, Garforth, J. and Mills, P. (1998) Beckett at Reading: Catalogue of the

Beckett Manuscript Collection at the University of Reading. Reading: White Knights Press and the Beckett International Foundation.

Butler, J. (1990a) Gender Trouble, London: Routledge.
. (1990b) 'Performative Acts and Gender Cons

- (1990b) 'Performative Acts and Gender Constit nomenology and Feminist Theory', in Performing Feminisms, ed. S.E. Case, Baltimore, MD: John Hopkins Press, 270-282. 


\section{Bibliography}

. (1993) Bodies that Matter: On the Discursive Limits of 'Sex', London: Routledge.

- (1997) The Psychic Life of Power: Theories in Subjection, Stanford, CA: Stanford University Press.

- (2004) Precarious Life: The Powers of Mourning and Violence, London \& New York: Verso. Press.

. (2005) Giving an Account of Oneself, New York: Fordham University

. (2006) 'Sexual Difference as a Question of Ethics: Alterities of the Flesh in Irigaray and Merleau-Ponty', in Feminist Interpretations of Maurice MerleauPonty, ed. D. Olkowski and G. Weiss, Philadelphia: Pennsylvania State University Press, 107-125.

Butler, L.S-J. (1992) ““A Mythology which with I am perfectly familiar”: Samuel Beckett and the Absence of God', in Irish Writers and Religion, ed. R. Welch, Gerrards Cross: Colin Smythe, Ltd., 169-184.

Carlson, M. (2001) The Haunted Stage: The Theater as Memory Machine, Ann Arbor: University of Michigan Press.

Carmen, T. and Hansen, M.B.N. (eds.) (2005) The Cambridge Companion to Merleau-Ponty, Cambridge \& New York: Cambridge University Press.

Caselli, D. (2005) Beckett's Dantes: Intertextuality in the Fiction and Criticism. Manchester: Manchester University Press.

Causey, M. (2006) Theatre and Performance in Digital Culture, London: Routledge.

Chabert, P. (1982) 'The Body in Beckett's Theatre', JOBS (8) 23-28.

Chapple, F. and Kattenbelt, C. (2007) Intermediality in Theatre and Performance. Amsterdam: Rodopi.

Chion, M. (1999) The Voice in Cinema, New York: Columbia University Press.

Clarke, B.K. and Ferrar, H. (1979) The Dublin Drama League 1919-1941, Dublin: Dolmen Press.

Cohn, R. (1962) The Comic Gamut, New Brunswick, NJ: Rutgers University Press.

- (1980) Just Play: Beckett's Theater, Princeton, NJ: Princeton University Press.

- (ed.) (1987) Beckett: Waiting for Godot: A Selection of Critical Essays, Basingstoke: Macmillan.

- (1990) 'The Femme Fatale on Beckett's Stage', in Women in Beckett: Performance and Critical Perspectives, ed. L. Ben-Zvi, Urbana and Chicago: University of Illinois Press, 162-171.

- (1999) 'The Becketts of Mabou Mines', in Samuel Beckett and the Arts, ed. L. Oppenheim, New York \& London: Garland Press, 217-236.

- (2001) A Beckett Canon, Ann Arbor: University of Michigan Press.

Connor, S. (1988) Samuel Beckett: Repetition, Theory and Text, Oxford: Blackwell.

-. (ed.) (1992a) Waiting for Godot and Endgame, New Casebooks series, Basingstoke: MacMillan.

- (1992b) 'Between Theatre and Theory: Long Observation of the Ray', in The Ideal Core of the Onion, ed. J. Pilling and M. Bryden, Reading: The Beckett International Foundation, 79-98.

- (2000) Dumbstruck: A Cultural History of Ventriloquism, Oxford: Oxford University Press.

- (2009) 'Beckett and Sartre: The Nauseous Character of All Flesh', in Beckett and Phenomenology, eds. U. Maude and M. Feldman, London: Continuum, $56-76$.

Cooey, P. (1994) Religious Imagination and the Body: A Feminist Analysis, New York \& Oxford: Oxford University Press.

Cooke, V. (1987) 'Beckett’s Prose in Performance', Romance Studies (11) 15-21. 
Crary, J. (1996) Techniques of the Observer: On Vision and Modernity in the Nineteenth Century, Cambridge, MA \& London: MIT Press.

Csordas, T.J. (1994) Embodiment and Experience: The Existential Ground of Culture and Self, Cambridge: Cambridge University Press, 1994.

Davis, T.C. (ed.) (2008) The Cambridge Companion to Performance Studies, Cambridge: Cambridge University Press.

Davis, T.C. and Postlewait, T. (eds.) (2003) Theatricality, Cambridge: Cambridge University Press.

Dante, A. (1961) The Divine Comedy, vol. 1, The Inferno, trans. J.D. Sinclair, Oxford: Oxford University Press.

Decroux, E. (1963) Paroles sur le Mime, Paris: Gallimard.

Deleuze, G. (1986) Cinema 1: The Movement-image, trans. H. Tomlinson and B. Habberjam, London: Athlone Press.

- (1995a) Cinema 2: The Time-Image, trans. H. Tomlinson and R. Galeta, Minneapolis: University of Minnesota Press, 1995.

- (1995b) 'The Exhausted', trans A. Uhlmann, SubStance (24.3.78) $3-28$.

- and Guattari, F. (1987) A Thousand Plateaus, trans. B. Massumi, Minneapolis: University of Minnesota Press.

Derrida, J. (1973) Speech and Phenomena and Other Essays on Husserl's Theory of Signs, Evanston, IL: Northwestern University Press.

- and Stiegler, B. (2002) Echographies of Television, trans. Jennifer Bajorek, Cambridge \& Malden, MA: Polity Press.

Descartes, R. (1985) The Philosophical Writings of René Descartes, trans. J. Cottingham, R. Stoothoff and D. Murdoch, vol. 1, Cambridge: Cambridge University Press.

- (1996) Meditations on First Philosophy: With Selections from the Objections and Replies, ed. and trans. J. Cottingham, Cambridge: Cambridge University Press.

Diamond, E. (1996) 'Brechtian Theory / Feminist Criticism: Towards a Gestic Feminist Criticism', in A Sourcebook of Feminist Theatre and Performance: On and Beyond the Stage, ed. C. Martin, London: Routledge, 120-135.

- (1997) Unmaking Mimesis: Essays on Feminism and Theatre, New York: Routledge.

- (2001) “"The Society of My Likes”: Beckett's Political Imaginary', SBTA (11) 383-388.

Diprose, R. (1994) The Bodies of Women: Ethics, Embodiment and Sexual Difference, London: Routledge.

Doane, M.A. (2003) 'The Close-Up: Scale and Detail in the Cinema', Differences: A Journal of Feminist Cultural Studies (14:3) 89-111.

Donald, J., Friedberg, A. and Marcus, L. (eds.) (1998) Close-Up: Cinema and Modernism, London: Cassell.

Dorcy, J. (1958) A la Rencontre de la Mime et des Mimes: Decroux, Barrault, Marceau, suivi de texts inédits de Étienne Decroux, Jean-Louis Barrault, Marcel Marceau, Neuilly-sur-Seine: Cahiers de Danse et Culture.

Douglas, M. (1991) Purity and Danger: An Analysis of the Concepts of Pollution and Taboo, London: Routledge.

Duckworth, C. (1972) Angels of Darkness, London: Allen and Unwin.

Ehrhard, P. (1976) Anatomie de Samuel Beckett, Basel: Birkhaser Verlag.

Eisenstein, S. (1957) Film Form Film Sense, ed. and trans. J. Leyda, New York: Meridian Books.

Elam, K. (1986) 'Not I: Beckett's Mouth and the Ars(e) Rhetorica', in Beckett at 80: Beckett in Context, ed. E. Brater, New York \& Oxford: Oxford University Press, 124-148. 


\section{Bibliography}

Engelberts, M. (2001) Défis du récit scénique: Formes et enjeux du mode narratif dans le théâtre de Beckett et de Duras, Geneva: Librairie Droz.

. (2003) 'Victor(ious) Retreats: Beckett's Eleutheria and Roger Vitrac's Departure from Surrealism', Assaph (17-18) 89-112.

- (2005/2006) 'Bordering on Death: Orpheus and Orphism in Beckett's Eleutheria', JOBS (15:1-2) 88-107.

- (2008) 'Film and Film: Beckett and Early Film Theory', in Beckett at 100: Revolving It All, ed. L. Ben-Zvi and A. Moorjani, Oxford: Oxford University Press, 152-165.

Esslin, M. (ed.) (1965), Samuel Beckett: A Collection of Critical Essays, Englewood Cliffs, NJ: Prentice Hall.

- (1982) Mediations: Essays on Brecht Beckett and the Media, New York: Grove Press.

Feldman, M. (2006) Beckett's Books: A Cultural History of Samuel Beckett's 'Interwar Notes', London: Continuum.

Feshbach, S. (1999) 'Unswamping a Backwater: On Samuel Beckett's Film', in Samuel Beckett and the Arts: Music, Visual Arts and Non-Print Media, ed. L. Oppenheim, New York \& London: Garland Press, 333-363.

Finter, H. (1997) 'The Body and its Doubles: On the (De)Construction of Femininity on Stage', trans. M. Griffin, Women and Performance (9.2) 119-141.

Foster, S.L. (2008) 'Movements contagion': The kinesthetic impact of performance, in The Cambridge Companion to Performance Studies, ed. T.C. Davis, Cambridge: Cambridge University Press, 46-59.

Foucault, M. (1977) Discipline and Punish: The Birth of the Prison, trans. A. Sheridan, Harmondsworth: Penguin.

Fournier, E. (1998) 'Marcel Mihalovici and Samuel Beckett: Musicians of Return', in Samuel Beckett and Music, ed. M. Bryden, Oxford: Clarendon Press, 131140.

Freedman, B. (1991), Staging the Gaze: Postmodernism, Psychoanalysis and Shakespearean Comedy, Ithaca, NY \& London: Cornell University Press.

Freud, S. (1919/1990) 'The "Uncanny"', in The Penguin Freud Library, vol. 14. London: Penguin, 335-376.

Frost, E. (1991) 'Fundamental Sounds: Recording Samuel Beckett's Radio Plays', Theatre Journal (43:3) 361-376.

- (1997) 'A "Fresh Go" for the Skull: Directing All That Fall, Samuel Beckett's Play for Radio', in Directing Beckett, ed. L. Oppenheim, Ann Arbor: University of Michigan Press, 186-219.

- (1998) 'The Note Man on the Word Man: Morton Feldman on Composing the Music for Samuel Beckett's Words and Music in The Beckett Festival of Radio Plays', in Samuel Beckett and Music, ed. M. Bryden, Oxford: Clarendon Press, 47-56.

- (1999) 'Mediatating On: Beckett, Embers, and Radio Theory', in Samuel Beckett and the Arts: Music, Visual Arts and Non-Print Media, ed. L. Oppenheim, New York \& London: Garland Press, 311-331.

— and Maxwell, J. (2006) 'Samuel Beckett's Notes Divers Holo[graph]: An Annotated Catalogue', SBTA (16) 19-199.

- and McMullan, A. (2003) 'The Blue Angel Beckett on Film Project: Questions of Adaptation, Aesthetics and Audience in Filming Beckett's Theatrical Canon', Assaph (17-18) 215-238.

Fuchs, E. (1996) The Death of Character, Bloomington: Indiana University Press.

Gallaher, S. (2005) How the Body Shapes the Mind, Oxford: Oxford University Press. 
Gane, N. and Haraway, D. (2006) 'When We Have Never Been Human, What Is to Be Done? Interview with Donna Haraway', Theory Culture Society (23:7-8) $135-158$.

Garber, D. (2000) Descartes Embodied: Reading Cartesian Philosophy Through Cartesian Science, Port Chester, NY: Cambridge University Press.

Garner, S.B. (1993) "'Still Living Flesh": Beckett, Merleau-Ponty, and the Phenomenological Body', Theatre Journal (45:4) 443-460.

- (1994) Bodied Spaces: Phenomenology and Performance in Contemporary Drama, Ithaca, NY: Cornell University Press.

Gontarski, S.E. (1985) The Intent of Undoing in Samuel Beckett's Dramatic Texts, Bloomington: Indiana University Press.

- (1987) 'Company for Company: Androgyny and Theatricality in Samuel Beckett's Prose', in Beckett's Later Fiction and Drama: Texts for Company, ed. J. Acheson and K. Arthur, Basingstoke: Macmillan, 193-202.

- (ed.) (1992) The Theatrical Notebooks of Samuel Beckett, vol. 2, Endgame, with a revised text, London: Faber and Faber.

. (ed.) (1999) The Theatrical Notebooks of Samuel Beckett, vol. 4, The Shorter Plays, New York: Grove Press.

- (2001) 'The Body in the Body of Beckett's Theatre', SBTA (11) 169-177.

. (2006) 'An Interview with Director Makoto Sato', JOBS (15:1-2) 186194.

- (2007) 'Viva, Sam Beckett, or Flogging the Avant-Garde', JOBS (16:1-2) $1-11$.

Grossman, E. (2004) La Défiguration: Artaud, Beckett, Michaux, Paris: Éditions de Minuit.

Grosz, E. (1994) Volatile Bodies: Toward a Corporeal Feminism, Bloomington \& Indianapolis: Indiana University Press.

- (1995) Space, Time and Perversion, London \& New York: Routledge.

Gussow, M. (1970) 'Jack MacGowran in the Works of Samuel Beckett', New York Times, 20 November.

- (1996) Conversations with (and about) Beckett. London: Nick Hern Books.

Halberstam, J. and Livingston, I. (eds.) (1995) Posthuman Bodies, Bloomington \& Indianapolis: Indiana University Press.

Hanson, M. (2006) Bodies in Code: Interfaces with Digital Media, London: Routledge.

Harmon, M. (ed.) (1998) No Author Better Served: The Correspondence of Samuel Beckett and Alan Schneider, Cambridge, MA \& London: Harvard University Press.

Harvey, L. (1970) Samuel Beckett: Poet and Critic, Princeton, NJ: Princeton University Press.

Hayles, N.K. (1999) How We Became Posthuman: Virtual Bodies in Cybernetics, Literature, and Informatics, Chicago \& London: University of Chicago Press.

Heath, S. (1981) Questions of Cinema, London \& Basingstoke: Macmillan.

Hegel, G.W.F. (1977) Phenomenology of Spirit, trans. A.V. Miller, Oxford: Clarendon Press.

Heidegger, M. (1977) The Question Concerning Technology and Other Essays, trans. W. Lovitt, New York: Harper and Row.

Herren, G. (2007) Samuel Beckett's Plays on Film and Television, New York \& Basingstoke: Palgrave Macmillan.

Hesla, D. (1971) The Shape of Chaos: An Interpretation of the Art of Samuel Beckett, Minneapolis: University of Minnesota Press.

Hill, L. (1990) Beckett's Fiction: In Different Words, Cambridge: Cambridge University Press, 1990. 
. (1992) 'Late Texts: Writing the Work of Mourning', SBTA (1) 10-25.

Hill, M.L. (1996) 'Developing a Blind Understanding: A Feminist Revision of Radio Semiotics', Tulane Drama Review (40:3) 112-120.

Hubert, M.C. (1987) Langage et corps fantasmé dans le théâtre des années cinquantes: Ionesco-Beckett-Adamov, Paris: Librairie José Corti.

Husserl, E. (1989) Ideas Pertaining to a Pure Phenomenology and to a Phenomenological Philosophy: Second Book, trans. R. Rojcewicz and A. Schuwer, Dordrecht: Kluwer Academic Publishers.

Irigaray, I. (1985) This Sex Which Is Not One, trans. C. Porter, Ithaca, NY: Cornell University Press.

. (1991) 'Women-mothers, the Silent Substratum', in The Irigaray Reader, ed. M. Whitford, Oxford: Blackwell, 47-52.

- (1993) An Ethics of Sexual Difference, trans. C. Burke and F. Gillian, Ithaca, NY: Cornell University Press.

The Irish Times (1931), 'Peacock Theatre: Three Foreign Plays', 20 February.

Jackson, S. (2003) 'Theatricality's Proper Objects: Genealogies of Performance and Gender Theory', in Theatricality, eds. T.C. Davis and T. Postlewait, Cambridge: Cambridge University Press, 186-213.

Juliet, C. (1995) Conversations with Samuel Beckett and Bram van Velde, trans. J. Tucker, Leiden: Academic Press Leiden.

Johnson, G.A. (1993) The Merleau-Ponty Aesthetics Reader, trans M.B. Smith, Evanston, IL: Northwestern University Press.

Jones, A. (1998) Body Art: Performing the Subject, Minneapolis: University of Minnesota Press.

- (2006) Self / Image: Technology, Representation and the Contemporary Subject, London: Routledge.

Jones, D.H. (2008) 'From Contumacy to Shame: Reading Beckett's Testimonies with Agamben', in Beckett at 100: Revolving It All, ed. L. Ben-Zvi and A. Moorjani, Oxford: Oxford University Press, 54-67.

Judovitz, D. (2001) The Culture of the Body: Genealogies of Modernity, Ann Arbor: Michigan University Press.

Kalb, J. (1989) Beckett in Performance, Cambridge: Cambridge University Press.

Kao, W.H. (2005/2006) 'Samuel Beckett in Taiwan: Cross-cultural Innovations and Significance', JOBS (15:1-2) 160-181.

Karmitz, M. and Beckett, S. (2001) Marin Karmitz, Samuel Beckett, Co mé die, Paris: Éditions du regard.

Katz, D. (1999) Saying I No More: Subjectivity and Consciousness in the Prose of Samuel Beckett, Evanson, IL: Northwestern University Press.

- (2004) 'Mirror Resembling Screens: Yeats, Beckett and . . . but the clouds ...', SBTA (4) 83-92.

- (2009) 'What Remains of Beckett: Evasion and History', in Beckett and Phenomenology, ed. U. Maude and M. Feldman, London \& New York: Continuum, 144-157.

Kedzierski, M. (1994) 'Beckett and the (Un)Changing Image of the Mind', SBTA (4) 149-159.

Kennedy, S. (1971) Murphy's Bed, Lewisburg, PA: Bucknell University Press.

Kennedy, S. (2003) “"A Lingering Dissolution”: All That Fall and Protestant Fears of Engulfment', Assaph (17-18) 247-261.

Kenner, H. (1968) Samuel Beckett: A Critical Study, Berkeley: University of California Press.

Kim, R. (2005) 'Severing Connections with Ireland: Women and the Irish Free State in Beckett's Writing', SBTA (15) 57-69.

Kirby, V. (1997) Telling Flesh: The Substance of the Corporeal, New York \& London: Routledge. 
Kleist, H. von (1978) 'On the Marionette Theatre', trans. Idris Parry, The Times Literary Supplement, 20 October.

Knowlson, J. (ed.) (1980) Samuel Beckett, Krapp’s Last Tape, Theatre Workbook 1, London: Brutus books.

- (ed.) (1985) Happy Days: The Production Notebook of Samuel Beckett, London: Faber \& Faber.

- (1986) 'Ghost Trio / Geister Trio', in Beckett at 80 / Beckett in Context, ed. E. Brater, Oxford \& New York: Oxford University Press, 193-207.

. (ed.) (1992) The Theatrical Notebooks of Samuel Beckett, vol. 3, Krapp's Last Tape, London, Faber \& Faber.

- (1996) Damned to Fame: The Life of Samuel Beckett, London: Bloomsbury.

. (2006) Beckett Remembering / Remembering Beckett: Uncollected Interviews with Samuel Beckett and Memories of Those Who Knew Him, London: Bloomsbury.

- (2007) 'Samuel Beckett: The Intricate Web of Life and Work', SBTA (16:1-2) 17-29.

_ and Haynes, J. (2003) Images of Beckett, Cambridge: Cambridge University Press.

- and McMillan, D. (eds.) (1994) The Theatrical Notebooks of Samuel Beckett, vol. 1, Waiting for Godot, London: Faber \& Faber.

and Pilling, J. (1979) Frescoes of the Skull: The Later Prose and Drama of Samuel Beckett, London: Calder.

Krance, C. (1993) Samuel Beckett's Company / Compagnie and A Piece of Monologue / Solo: A Bilingual Variorum Edition, New York: Garland Press.

Kruks, S. (1981) The Political Philosophy of Merleau-Ponty, Atlantic Highlands, NJ: Humanities Press.

Kristeva, J. (1982) Powers of Horror: An Essay on Abjection, trans. L. Roudiez, New York: Columbia University Press.

- (1984) Revolution in Poetic Language, trans. M. Waller, New York: Columbia University Press.

Krysinski, W. (1981) 'Semiotic Modalities of the Body in Modern Drama', Poetics Today (213): 141-161.

Kuppers, P. (2003) Disability and Contemporary Performance: Bodies on Edge, New York \& London: Routledge.

Lacan, J. (1977) The Four Fundamental Concepts of Psychoanalysis, ed. J-A. Miller, trans. A. Sheridan, London: The Hogarth Press.

- (1988) The Seminar of Jacques Lacan, Book II: The Ego in Freud's Theory and in the Technique of Psychoanalysis, 1954-1955, trans. S. Tomaselli, Cambridge: Cambridge University Press.

- (2001) Écrits: A Selection, trans. A. Sheridan, London: Routledge.

Ladrón de Guevara, V.M.R. (2007) 'Performing Beckett as an Intercultural Actor', Performance Research (12:1) 110-119.

Lane, R. (ed.) (2002) Beckett and Philosophy, Basingstoke: Palgrave.

Laplanche, J. and Pontalis, J.B. (1973) The Language of Psychoanalysis, trans. D. Nicholson-Smith, London: The Hogarth Press and the Institute of Psychoanalysis.

Laqueur, T. (1990) Making Sex: Body and Gender from the Greeks to Freud, Cambridge, MA: Harvard University Press.

Lastra, J. (2009) 'Bunuel, Bataille and Buster, or the Surrealist Life of Things', Critical Quarterly (51:2) 16-38.

Lawley, P. (1994) 'Stages of Identity: From Krapp's Last Tape to Play', in The Cambridge Companion to Beckett, ed. J. Pilling, Cambridge: Cambridge University Press, 88-105.

Laws, C. (2003) 'Beethoven's Haunting of Beckett's Ghost Trio', Assaph (17-18) 197-213. 


\section{Bibliography}

Leabhart, T. (1989) Modern and Postmodern Mime, Basingstoke: Macmillan.

- (2004) 'Jacques Copeau, Étienne Decroux, and the "Flower of Noh", New Theatre Quarterly (20) 315-330.

Lehmann, H.-T. (2006) Postdramatic Theatre, trans. K. Jürs-Munby, London \& New York: Routledge.

Leppert, R. (1993) The Sight of Sound: Music, Representation and the History of the Body, Berkeley, Los Angeles \& London: University of California Press.

Levin, D.M. (ed.) (1993) Modernity and the Hegemony of Vision, Berkeley \& London: University of California Press.

Lewis, J. (1986) 'Beckett et la caméra', Revue d'Esthétique, numéro spécial hors série, 371-379.

Lloyd, G. (1984) The Man of Reason: 'Male' and 'Female' in Western Philosophy, London: Methuen.

Lucbert, F. (1995) 'The Pen and the Eye: The Politics of the Gazing Body', in Vision and Textuality, ed. S. Melville and B. Readings, Hampshire \& London: Macmillan, 1995.

Lyons, C. (1964) 'Beckett's Endgame: An Anti-myth of Creation', Modern Drama (7) 204-209.

Lyotard, J.-F. (2000) 'Can Thought Go On without a Body', in Posthumanism, ed. N. Badmington, Basingstoke: Palgrave Macmillan, 129-140.

MacGowran, J. (1973) 'MacGowran on Beckett: Interview by Richard Toscan', Theatre Quarterly (3:2) 15-22.

MacNeice, L. (1947) The Dark Tower and Other Radio Scripts, London: Faber \& Faber.

Maier, M. (2001) 'Geistertrio: Beethoven's Music in Samuel Beckett's Ghost Trio', SBTA (11) 267-278.

- (2002) 'Geistertrio: Beethoven's Music in Samuel Beckett's Ghost Trio (Part 2)', SBTA (12) 313-320.

Malina, D. (1992) 'Whom Else: Gendered Consciousness and Wholeness in Krapp's Last Tape and Rockaby', Modern Drama (35:3) 395-408.

Maude, U. (2002) 'The Body of Memory: Beckett and Merleau-Ponty', in Beckett and Philosophy, ed. R. Lane, Basingstoke: Palgrave, 108-122.

- (2009) Beckett, Technology and the Body, Cambridge: Cambridge University Press.

- and Feldman, M. (2009) Beckett and Phenomenology, London \& New York: Continuum.

McConachie, B. (2007) 'Falsifiable Theories for Theatre and Performance', Theatre Journal (59) 553-577.

McMillan, D. and Fehsenfeld, M. (1988) Beckett in the Theatre, London \& New York: Calder and Riverrun.

McMullan, A. (1993) Theatre on Trial: Samuel Beckett's Later Drama, London: Routledge.

- (1997) 'Versions of embodiment / Visions of the Body in Beckett's but the clouds ...', SBTA (6) 353-364.

. (1998) 'Performing Vision(s): Perspectives on Spectatorship in Beckett's Drama', in Samuel Beckett: A Casebook, ed. J. Jeffers, New York \& London: Garland Press, 133-158.

- (2006) 'Generic Mutations of a Dramatic Fragment: "J.M.Mime", SBTA (16) 333-346.

- (2007) 'Mutated Bodies: Stage Performances of Beckett's Late Prose Texts', Performance Research (12) 57-65.

McWhinnie, D. (1959) The Art of Radio, London: Faber and Faber.

Merleau-Ponty, M. (1962) Phenomenology of Perception, trans. C. Smith, London \& Henley: Routledge \& Kegan Paul. 
. (1964a) Signs, trans. R.C. McCleary, Evanston, IL: Northwestern University Press.

- (1964b) The Primacy of Perception and Other Essays on Phenomenological Psychology, the Philosophy of Art, History and Politics, ed. J.M. Edie, trans. C. Dallery, Evanston, IL: Northwestern University Press.

. (1968) The Visible and the Invisible, followed by working notes, ed. C. Lefort, trans. A. Lingus, Evanston, IL: Northwestern University Press.

- (1969) Humanism and Terror: An Essay on the Communist Problem, trans. J. O’Neill, Boston: Beacon Press.

- (2004) The World of Perception, trans. O. Davis, London: Routledge.

Metz, C. (1982), Psychoanalysis and Cinema: The Imaginary Signifier, trans. C. Britton, A. Williams, B. Brewster and A. Guzzetti, Basingstoke: Palgrave Macmillan.

Milutis, J. (1996) 'Radiophonic Ontologies and the Avant-Garde', Tulane Drama Review (40:3) 63-79.

Moorjani, A. (1998) 'En attendant Godot on Michel Polac's Entrée des auteurs', SBTA (7) 47-56.

- (2000) 'Beckett et le moi-peau: Au delà du fétishisme matrichiel', SBTA (10) 63-70.

- (2003), 'Diogenes Lampoons Alexandre Kojève: Cultural Ghosts in Beckett's Early French Plays', Assaph (17-18) 69-88.

- . (2008) 'Le complexe de prométhée ou sous le signe du feu: Tyrannie et volonté de savoir chez Beckett', SBTA (20) 23-32.

Morfee, A. (2005) Antonin Artaud's Writing Bodies, Oxford: Oxford University Press.

Moran, D. (2000) Introduction to Phenomenology, London \& New York: Routledge.

Morot-Sir, E. (1976) 'Samuel Beckett and Cartesian Emblems', in Samuel Beckett and the Art of Rhetoric, eds. E. Morot-Sir, H. Harper and D. McMillan, Chapel Hill: University of North Carolina Press, 25-104.

Murphy, P. (1982) 'The Nature of Allegory in The Lost Ones, or the Quincunx Realistically Considered', JOBS (7) 71-88.

Murray, C. (2007) 'Taking a Position: Beckett, Mary Manning, and Eleutheria (1947)', in Ireland on Stage: Beckett and After, ed. H. Mikami, M. Okamuro and N. Yagi, Dublin: Carysfort Press, 55-68.

Naito, J.T. (2008) 'Writing Silence: Samuel Beckett's Early Mimes', SBTA (20) 393-402.

O’Brien, E. (1986) The Beckett Country, Dublin \& London: The Black Cat Press, in association with Faber \& Faber.

O'Brien Johnson, T. (1982) Synge: The Medieval and the Grotesque, London: Colin Smythe.

O'Donovan-Anderson, M. (1996) The Incorporated Self: Interdisciplinary Perspectives on Embodiment, New York \& London: Rowman \& Littlefield.

Olkowski, D. and Weiss, G. (eds.) (2006) Feminist Interpretations of Maurice Merleau-Ponty, Philadelphia: Pennsylvania State University Press.

Ouimet, A. (1992) 'Textual Androgny in Beckett's Later Work: Prose for Performance', SBTA (1) 138-142.

Oppenheim, L. (ed.) (1997) Directing Beckett, Ann Arbor: University of Michigan Press.

. (ed.) (1999) Samuel Beckett and the Arts, New York \& London: Garland Publishing.

- (2000) The Painted Word: Samuel Beckett's Dialogue with Art, Ann Arbor: University of Michigan Press.

- (ed.) (2004) Palgrave Advances in Samuel Beckett Studies. Basingstoke: Palgrave Macmillan. 


\section{Bibliography}

. (2005) 'The Uncanny in Beckett', in Real Absence: Beckett, Joyce and the Art of the Negative, ed. C. Jaurretche, Amsterdam \& Atlanta: Rodopi, 125-140.

Pavis, P. (1982) Languages of the Stage: Essays in the Semiology of the Theatre, New York: Performing Arts Journal Publications.

- (2003) Analyzing Performance: Theater, Dance and Film, trans. D. Williams, Ann Arbor: University of Michigan Press.

Phelan, P. (1993) Unmarked: The Politics of Performance, London \& New York: Routledge.

- (2004) 'Lessons in Blindness from Samuel Beckett', Publications of the Modern Language Association of America (119:5): 1279-1288.

Pilling, J. (1976) Samuel Beckett, London, Henley \& Boston: Routledge \& Kegan Paul.

- (1998) 'Proust and Schopenhauer: Music and Shadows', in Samuel Beckett and Music, ed. M. Bryden, Oxford: Clarendon Press, 173-178.

- (2006) A Samuel Beckett Chronology, Basingstoke: Palgrave Macmillan.

Pountney, R. (1994) 'Beckett and the Camera', SBTA (4) 41-52.

Power, C. (2008) Presence in Play: A Critique of Theories of Presence in the Theatre, Amsterdam: Rodopi.

Protopapa, E. (2007) 'A Phantom in European Choreography: What Is Beckett Doing to Us Dance-makers, or, a Series of Realizations, Three Instances and an Afterthought', Performance Research (12:1) 20-34.

Rabaté, J.M. (1996) 'Beckett's Ghosts and Fluxions', SBTA (5) 3-40.

Rainford, L. (2003) 'How to Read the Image? Beckett's Televisual Memory', in Literature and Visual Technologies: Writing after Cinema, eds. J. Murphet and L. Rainford, Basingstoke: Palgrave Macmillan, 177-196.

Rancière, J. (1977) 'Interview: The Image of Brotherhood', trans Kari Hanet, Edinburgh Magazine (2) 26-31.

Rayner, A. (1994) To Do, To Act, To Perform: Drama and the Phenomenology of Action, Ann Arbor: University of Michigan Press.

Richard, N. (1986) 'The Rhetoric of the Body', Art and Text (21) 65-73.

Roach, J. (1996) Cities of the Dead: Circum-Atlantic Performances, New York: Columbia University Press.

— . (2001) 'The Great Hole of History: Liturgical Silence in Beckett, Osofisan, and Parks', The South Atlantic Quarterly (100:1) 307-317.

Roof, J. (1999) 'Close Encounters on Screen: Gender and the Loss of the Field', Genders 29, accessed 26 July 2007 at http://www.genders.org/g29/g29_roof.html.

Rose, J. (1986) Sexuality in the Field of Vision, London: Verso.

Ruler, H. van and Uhlmann, A. (eds.) (2006) Geulincx's Ethics: With Samuel Beckett's Notes, Leiden \& Boston: Brill.

Sawday, J. (1995) The Body Emblazoned: Dissection and the Human Body in Renaissance Culture, London \& New York: Routledge.

Scanlan, R.N. (1987) 'A Voice Comes to One in the Dark', Romance Studies (11) 23-8.

Scarry, E. (1985) The Body in Pain: The Making and Unmaking of the World, New York \& Oxford: Oxford University Press.

Schechner, R. (2002) Performance Studies: An Introduction, London: Routledge.

Schilder, P. (1950/2000) The Image and Appearance of the Human Body: Studies in the Constructive Energies of the Psyche, London: Routledge.

Schneider, A. (1975) 'Any Way You Like, Alan: Working with Beckett', Theatre Quarterly (5:19) 27-38.

Schopenhauer, A. (1883) The World as Will and Idea, 3 vols., trans. R.B. Haldane and J. Kemp, London: Routledge and Kegan Paul.

Shaviro, S. (2006) The Cinematic Body, Minneapolis \& London: University of Minnesota Press. 
Siess, J. (2003) 'The Actor's Body and Institutional Tensions: From Act Without Words I to Not I', in Assaph (17-18) 297-307.

Silverman, K. (1988) The Acoustic Mirror: The Female Voice in Psychoanalysis and Cinema, Bloomington \& Indianapolis: Indiana University Press.

- (1992) Male Subjectivity at the Margins, New York \& London: Routledge.

- (1995) The Threshold of the Visible World, London: Routledge.

Simon, B. (2003) 'Towards a Critique of Posthuman Futures', Cultural Critique (53) 1-9.

Shildrick, M. and Mykitiuk, R. (2005) Ethics of the Body: Postconventional Challenges, Cambridge, MA: MIT Press.

Smith, F.N. (2002) Beckett's Eighteenth Century, Basingstoke \& New York: Palgrave.

Smith, K. (2007) 'Abject Bodies: Beckett, Orlan, Stelarc and the Politics of Contemporary Performance', Performance Research (12:1) 66-76.

Smith, R. (ed.) (2009) Beckett and Ethics, London \& New York: Continuum.

Sobchack, V. (1992) The Address of the Eye: A Phenomenology of Film Experience, Princeton, NJ: Princeton University Press.

Sofer, A. (2003) The Stage Life of Props, Ann Arbor: University of Michigan Press.

States, B.O. (1978) The Shape of Paradox: An Essay on Waiting for Godot, Berkeley, Los Angeles \& London: University of California Press.

- (1985) Great Reckonings in Little Rooms: On the Phenomenology of Theater, Berkeley, Los Angeles \& London: University of California Press.

Striff, E. (ed.) (2003) Performance Studies, Basingstoke: Palgrave Macmillan.

Takahashi, Y. (1982) 'Samuel Beckett and the Noh', Encounter (58:4), 66-73.

Tajiri, Y. (2007) Samuel Beckett and the Prosthetic Body: The Organs and Senses in Modernism, Basingstoke: Palgrave Macmillan.

Taylor-Batty, M. (2007) Roger Blin: Collaborations and Methodologies, Bern: Peter Lang.

Taylor-Batty, M. and Taylor-Batty, J. (2008) Samuel Beckett's Waiting for Godot, London: Continuum Books.

Tonning, E. (2007) Samuel Beckett's Abstract Drama: Works for Stage and Screen, 1962-1985. Oxford: Peter Lang.

Trezise, T. (1990) Into the Breach: Samuel Beckett and the Ends of Literature, Princeton, NJ: Princeton University Press.

Tubridy, D. (2007) 'Sounding Spaces: Aurality in Samuel Beckett, Janet Cardiff, and Bruce Neumann', Performance Research (12:1) 5-11.

Van Hulle, D. (2007) “"Accursed Creator": Beckett, Romanticism and the "Modern Prometheus", SBTA (18) 15-29.

Voights-Virchow, E. (2001) 'Quad I and Teletubbies or: "Aesthetic" Panopticism versus Reading Beckett', SBTA (11) 210-218.

. (2002) 'Face Values: Beckett Inc., The Camera Plays and Cultural Liminality’, JOBS (10:1-2) 119-135.

Warr, T. (ed.) (2000), The Artist's Body, survey by Amelia Jones, London: Phaidon Press.

Watson, D. (1991) Paradox and Desire in Beckett's Fiction, London: Macmillan.

Weller, S. (2006) Beckett, Literature and the Ethics of Alterity, Basingstoke: Palgrave Macmillan.

Welton, D. (ed.) (1998) Body and Flesh: A Philosophical Reader, Oxford: Blackwell.

White, H. (1998) " "Something is taking its Course": Dramatic exactitude and the Paradigm of Serialism in Samuel Beckett', in Samuel Beckett and Music, ed. M. Bryden, Oxford: Clarendon Press, 159-171.

Whitelaw, B. (1996) Billie Whitelaw, Who He?, London: St Martin's Press. 


\section{Bibliography}

Wills, C. (2007) That Neutral Island: A Cultural History of Ireland during the Second World War, London: Faber \& Faber.

Wilmer, S. (ed.) (1992) Beckett in Dublin, Dublin: Lilliput Press.

Wilshire, B. (1982) Role-Playing and Identity: The Limits of Theatre as Metaphor, Bloomington: Indiana University Press.

Wilson, S. (2002) 'Krapp's Last Tape and the Mania in Manichaeism', SBTA (12) 131-144.

Wood, J. (ed.) (1998) The Virtual Embodied, London, Routledge.

Worth, K. (1990) 'Women in Beckett's Radio and Television Plays', in Women in Beckett: Performance and Critical Perspectives, ed. L. Ben-Zvi, Urbana \& Chicago: University of Illinois Press, 236-242.

- (1998) 'Words for Music Perhaps', in Samuel Beckett and Music, ed. M. Bryden, Oxford: Clarendon Press, 9-20.

Worthen, W.B. (1991) Modern Drama and the Rhetoric of Theatre, Berkeley: University of California Press.

- (2005) Print and the Poetics of Modern Drama, Cambridge: Cambridge University Press.

Young, J.R. (1987) The Beckett Actor: Jack MacGowran, Beginning to End, Beverley Hills, CA: Moonstone Press.

Zarilli, P. (2009) Psychophysical Acting: An Intercultural Approach after Stanislavski, London \& New York: Routledge.

Zilliacus, C. (1976) Beckett and Broadcasting: A Study of the works of Samuel Beckett for and in Radio and Television, Abo: Abo Akademi.

Zinman, T. (1994) 'Eh Joe and the Peephole Aesthetic', SBTA (4) 53-64.

\section{MANUSCRIPT MATERIAL CONSULTED}

The Mabou Mines Archive, MSS 133, The Fales Library, New York University

Beckett Manuscripts and Letters Consulted

Harry Ransom Centre, University of Austin, Texas Samuel Beckett Collection (HRC)

HRC 17.7: 'Mongrel Mime'.

HRC 9.3: Jack MacGowran Correspondence, 1960-1972.

HRC Oversize Box 1. Beginning to End. Samuel Beckett, Reg No 12069.

Trinity College Dublin (TCD)

TCD MS 4664: 'J.M. Mime'.

TCD MS 10948: Barbara Bray Correspondence.

TCD MS 10971/7 and TCD MS 10971/8: Beckett's Psychology Notes.

University of Reading Beckett Collection (UoR)

UoR MS 1227/7/16/1: 'Mime du rêveur A'.

UoR MS 1227/7/16/3 and MS 2927: Petit Odéon Fragments.

UoR MS 2928: Fragments Prose début 68, including 'Film video-cassette'.

UoR MS 2931 and MS 2932: 'Espace souterrain'.

UoR MS 3458-3461: Manuscript and Typescript of 'Human Wishes' and research notes.

UoR MS 5060: Pamela Mitchell correspondence.

UoA MS 5100 COH: Ruby Cohn Correspondence. 